Journal of the History of the Behavioral Sciences, Vol. 44(2), 119-145 Spring 2008 Published online in Wiley Interscience (www.interscience.wiley.com). DOI 10.1002/jhbs.20303 (C) 2008 Wiley Periodicals, Inc.

\title{
FROM VYGOTSKY TO VYGOTSKIAN PSYCHOLOGY: INTRODUCTION TO THE HISTORY OF THE KHARKOV SCHOOL
}

\author{
ANTON YASNITSKY AND MICHEL FERRARI
}

\begin{abstract}
Around the end of the 1920s, Vygotsky introduced his integrative framework for psychological research to the Soviet Union. This framework was not abandoned and forgotten until its rediscovery in Russia and America in the 1950s, as some claim. In fact, even after his untimely death in 1934, Vygotsky remained the spiritual leader of a group of his former students and collaborators, who became known as the Kharkov School. This paper reconstructs the early intellectual history of Vygotskian psychology, as it emerged, around the time of Vygotsky's death, in the research program of the Kharkov School.
\end{abstract}

\section{Introduction: Vygotskian Psychology AND the Kharkov SchoOL}

Not only was Lev Vygotsky an extremely talented and versatile psychologist, he was also a gifted teacher, fostering a generation of younger scholars who continued his wide-ranging research, even after his untimely death in 1934. From the 1920s through the early 1930s, Vygotsky, his closest collaborators-Alexander Luria and Aleksei N. Leontiev-and their associates, conducted a wide range of psychological studies on verbal thinking and practical intellect in children, the development of memory and attention, concept formation, educational psychology, the psychology of art, human developmental pathology, neuropsychology, and the ethno-cultural study of minorities.

Behind this seemingly eclectic array of studies initiated by Vygotsky stands a profound, highly ambitious theoretical and methodological framework (Vygotsky, 1927/1997). For a variety of reasons, Vygotskian psychology after Vygotsky developed in several directions that no longer readily reveal their common source. For example, there is no immediately apparent link between Luria's early cross-cultural Central Asian expeditions and his neuropsychology; Leontiev's theorizing on activity, consciousness, and personality; Zaporozhets' psychology of perception, movement, or emotion; Zinchenko's psychology of involuntary remembering; Elkonin's research on the psychology of play and learning; Galperin's quest to define the object of distinctly psychological research; or Bozhovich's psychology of personality development (Minick, 1997). Furthermore, while the names of Luria and Leontiev are quite familiar in the West, outside Russia little is known about other students of Vygotsky and their work. James Wertsch (1994) is right to say that "This lacuna in our knowledge is clearly our loss."

ANTON YASINITSKY is a Ph.D. candidate at the Ontario Institute for Studies in Education (OISE), University of Toronto (UofT). He is doing research on the history of post-Vygotskian psychology (cultural-historical theory and activity-oriented psychology) funded by the grants from Social Sciences and Humanities Research Council of Canada and Canadian Institute of Ukrainian Studies (CIUS). Among his other interests are modern day applications of Vygotskian theory in developmental psychological and educational research. His most recent publication is "Rethinking the early history of post-Vygotskian psychology: The case of the Kharkov School," History of Psychology (with M. Ferrari, 2008, in press). Email: ayasnitsky@oise.utoronto.ca.

Michel Ferrari, PhD, is Associate Professor at the Ontario Institute for Studies in Education (OISE) at the University of Toronto. Dr. Ferrari completed his Ph.D. at the University of Quebec at Montreal. He has co-edited books on Self-Awareness (Guilford, 1998) and most recently on Teaching for Wisdom (Springer, 2008) and the Developmental Relations Between Mind, Brain \& Education: Essays in honour of Robbie Case (Springer, in press). He is currently editing a special issue of History of the Human Sciences, on the history of the science of consciousness.Email: mferrari@oise.utoronto.ca 
Several historical studies do focus on specific members of Vygotsky's circle, beginning with Vygotsky himself; ${ }^{1}$ however, none of these studies show how all these individual threads were intertwined within a shared framework for research. A number of scholars advocate a contextual or situational approach to the history of psychology (Danziger, 1990), specifically, to the history of Vygotskian psychology — one that takes the larger social and cultural context and the multiple interrelations between different actors and their ideas into account (Shchedrovitskii, 1980/2004; Stetsenko, 2003, 2004, 2005; Stetsenko \& Arievitch, 2004). Although there have been a few recent attempts to present the big picture of the history of Vygotskian psychology (Karpov, 2005; Venger, 1994; V. P. Zinchenko \& Morgunov, 1994), they are all limited in one way or another. A complete analysis of the complex interrelations between all the immediate students of Vygotsky and their followers - the major figures of the school-still remains to be done. ${ }^{2}$

This paper is a first step toward creating a more comprehensive portrait of the Vygotsky circle and its impact on psychology. Specifically, we focus on a group of Vygotsky's students who left Moscow in the early 1930s to establish a research center in the Ukrainian city of Kharkov, relatively far from the dangers of life in the capital of Stalin's Soviet Union-a group that writers in the history of science typically refer to as the Kharkov group, or the Kharkov School of Psychology (Bakhurst, 1990; Cole, 1980; Ivanova, 1995, 2002; Kozulin, 1986, 1990; A. A. Leontiev, 2005; A. N. Leontiev, 1999; Sereda, 1994; Sokolova, 2003; Valsiner, 1988; Yasnitsky \& Ferrari, 2008; V. P. Zinchenko, 2003; V. P. Zinchenko \& Morgunov, 1994).

In fact, the history of the Kharkov school in the 1930s has been called a "blank spot in the historiography of psychology" (Sokolova, 2003), and a "major hiatus in American knowledge about Soviet psychological research" (Cole, 1977). The only systematic account we have of the early Kharkov school, and of research done there in the 1930s, comes from the personal notes of Alexei N. Leontiev, nominal leader of the school. They were first presented by his son Alexei A. Leontiev (A. A. Leontiev, 1983) - a prominent psychologist himself — and first published in 1988 under the title Materials on Consciousness (A. N. Leontiev, 1940-1941/1988). The impact of this publication was considerable: Leontiev's account has been repeated and disseminated by many later authors (Ivanova, 1995, 2002; A. A. Leontiev, 2005; Sokolova, 2001) and is thought to be virtually the sole, or certainly the most authoritative, source on the history of the school.

However, there are several reasons to question the reliability of Leontiev's account. First, consider the context of Leontiev's presentation. By his own admission, in these Materials on Consciousness, Leontiev did not attempt to recount the entire history of the school, but - like elsewhere (A. N. Leontiev, 1967; 1967/1983) - he focused on how study of the specific problem of consciousness evolved in the Soviet psychology. Second, Leontiev presents a very detailed and thorough report on research done in Kharkov in the first half of the 1930s (the period of 1932-1933 and 1934-1935 that Leontiev refers to as the first and the second

1. For example, we recommend the following studies of Vygotsky (Davydov, Zinchenko, Munipov, \& Radzikhovskii, 1981; Kozulin, 1990; Minick, 1997; Puzyrei, 1986; Van der Veer \& Valsiner, 1991, 1994; Veresov, 1999; Vygodskaya \& Lifanova, 1996, 1999); as well as Luria (Cole, 1979; Cole \& Levitin, 2006; Homskaya, 1992/2001; E. A. Luria, 1994); A. N. Leontiev (A. A. Leontiev, Leontiev, \& Sokolova, 2005; Zaporozhets, Zinchenko, Ovchinnikova, \& Tikhomirov, 1983); Galperin (Arievitch \& Stetsenko, 2000; Arievitch \& van der Veer, 1995; Haenen, 1996; Van der Veer \& Arievitch, 1994; Van Geert, 1987; V. P. Zinchenko, 1993); P. Zinchenko (Bocharova, 1978, 1978/1979; Laktionov \& Sereda, 1993; Mescheryakov, 2003; Sereda, 1984, 1984/1994); and Zaporozhets (Aranovskaya-Dubovis \& Zaika, 1995; Dubovis \& Khomenko, 1985; Paramonova, 2005; Venger, 1985; V. P. Zinchenko, 1995, 2006).

2. Complete understanding of the intellectual circle within which Vygotskian psychology is situated requires that one understand, for example, its relations to the Georgian school of psychology founded by Dimitry Uznade (Usnadze); Gestaltpsychologie of Koffka, Köhler, Lewin; the developmental psychology of Jean Piaget; and the activity-oriented psychological school of Sergei Rubinshtein. A truly comprehensive study would require analyzing the evolution of the ideas of Levina, Morozova, Slavina, Shif, Zeigarnik, Birenbaum, Zankov, Menchinskaya, Solov'ev, to name a few, some of whom developed in directions quite different from Vygotsky's own views. 
cycle of research, respectively). In contrast, the second half of the 1930s, or the third and the fourth cycles of research (1935-1936 and from 1936 onward), is only briefly outlined. This second half of the 1930s is precisely when Leontiev left Kharkov for Moscow and, later, Leningrad, which might explain why his report on the research done in Kharkov on that time is, presumably, so fragmentary. Third, even a cursory review of the studies published by members of the Kharkov school in the 1930s reveals many discrepancies between Leontiev's account and the research done. For example, even studies on sensation and perceptual development, or on animal psychology (zoopsychology), foundational for Leontiev's doctoral dissertation-completed by 1939 and defended in Moscow in 1940 (and so obviously known to him) - are not included in his Materials on Consciousness.

These lacunae in Leontiev's canonical story set the stage for our own study of the history of the Kharkov School, and of other early Vygotskian psychology after Vygotsky. ${ }^{3}$

\section{Research Data AND Historical Evidence}

This paper is based on an analysis of publications made during the prewar period between 1931 and 1941 and materials from later publications, as well as archival materials from Kharkov. ${ }^{4}$ In addition to consulting previously published studies, the first author visited archives and libraries in Kharkov, where he uncovered many previously undiscovered texts from and about the early Kharkov school. The sources that we used in this study fall under several general categories:

1. Research overviews found in a number of publications of the 1930s-1960s describing the main problems and themes of their research (Galperin, 1934; Goldenberg, 1934; Kolomiets', 1934; Lebedinskii, 1933a, 1936a; A. R. Luria, 1960; Rokhlin, 1936a, 1936b; Rybnikov, 1940; Shmelkin, 1934; Zeigarnik \& Rubinshtein, 1960).

2. Secondary literature, including compiled lists of authors' publications and commentaries to the volumes of selected works of the key figures typically prepared by their students or collaborators. For example, bibliographies are available for Bozhovich, Elkonin, Leontiev, Luria, and Zaporozhets (see Bozhovich, 1995; Elkonin, 1989a; Homskaya, 1992/2001; A. A. Leontiev, Leontiev, \& Sokolova, 2005; A. N. Leontiev, 1983; A. R. Luria, 2003; Zaporozhets, 1986). Another important resource is biographic and memoir literature by the scientists themselves or the members of their families (Elkonin, 1983, 1983/1984; Galperin, 1983, 1983/1984; Ginevskaya, 2005; Haenen \& Galperin, 1989; A. N. Leontiev, 1976/1986, 1999; A. N. Leontiev \& Leontiev, 2005; A. R. Luria, 1979, 1982; E. A. Luria, 1994; Morozova, 1983; Vygodskaya \& Lifanova, 1996, 1999).

\footnotetext{
3. Our paper provides an overview of studies done at the Kharkov school in the 1930s. While Kharkov is our main focus, the work done there is intimately connected to that done in Moscow, Leningrad, and Poltava that need to be taken into account to really understand the directions Vygotskian psychology took at that time. Thus, in this paper we (somewhat illegitimately) refer to all these studies as belonging to the Kharkov School of psychology. Our very inclusive use of the term Kharkov school serves as an umbrella term for a range of post-Vygotskian studies done in the Soviet Union soon after the death of Vygotsky and continuing until the beginning of the Soviet-German war (WWII). One of the reasons for doing this is that the considerable mobility of the individual members of the group between 1930 and 1940 makes it virtually impossible to clearly distinguish between the Moscow, Leningrad, and Kharkov periods in the lives of Vygotsky, Luria, and Leontiev as well as several other individuals, who frequently commuted between these three cities, working and studying at a number of organizations in all three cities simultaneously.

4. There is an increasing scholarly interest in Soviet psychology of the 1930s, and many previously unpublished materials have recently been published (A. A. Leontiev, Leontiev, \& Sokolova, 2005; A. N. Leontiev, 1994, 2003; A. R. Luria, 2003; E. A. Luria, 1994; Voiskunskii, Zhdan, \& Tikhomirov, 1999; Vygodskaya \& Lifanova, 1996, 1999). Even so, resources on the history of this period of the development of Vygotskian psychology remain extremely scarce. Publications by Vygotskian scholars in 1930s are especially rare and inaccessible because many are written in Ukrainian - and few of those written in Russian have been included in later republications, nor have many been translated into English.
} 
3. Archival materials, including official documents (e.g., reports, orders, personal files, stenographic transcripts) from the main organizations within which research was done.

4. Manuscripts of that time, some of which still remain unpublished (Galperin, 1936; Lebedinskii, 1938a; A. R. Luria, 1941; G. I. Voloshin, 1939; Zaporozhets \& Lukov, 1936). A number of important manuscripts have been reported to exist (Bassin, 1938; A. R. Luria, 1937, 1940; Zaporozhets, 1934, 1937, 1939b; Zaporozhets \& Asnin, 1934), but we do not yet have access to these.

The relationships between all this material are enormously complex, making systematic scientific analysis difficult. Often a completed study was only available to members of the "inner circle" of the school, even though it clearly influenced subsequent research. At its best, the earlier research was briefly presented in the later works by the members of the school, and the full text versions of these scholarly papers are still not available to the broader research community. Quite often a researcher on the history of science in the Soviet Union of that period has to take into account the phenomenon of "retroactive impact" of early unpublished studies on the later works. Sometimes such studies are published much later. ${ }^{5}$

\section{History OF THE KHARKOv SchOOL}

\section{The Decade of 1931-1941: General Overview}

The history of the Kharkov school of psychology can be logically divided into two parts: (1) 1931-1936 marks the establishment of the Kharkov school and its institutionalization; (2) 1938-1941 is a time of maturation and scientific reflection. The boundary between the two, 1936-1937, shows a relative decrease in research and the (presumably deliberate) "disappearance" of members of the school from public life.

Several things are worth noting about the period of 1931-1936 and the establishment of the Kharkov school: First, there was the meeting of the Moscow and Kharkov researchers, and the establishment of a joint research group. Second, interdisciplinary research centers were founded at three separate institutions in Kharkov: the Ukrainian Psychoneurological Academy (UPNA), Ukrainian Scientific Institute of Pedagogy (UNDIP), and Kharkov State Pedagogical Institute (KDPI). Third, between 1933-1936 the younger generation scholars-Zaporozhets, Zinchenko, Galperin, Asnin, Lukov, Bozhovich, Khomenko, Bassin, and Aranovskayacompleted their PhD (Candidate of Science) studies. Fourth, the UNDIP was transferred from

5. The seventy-year history surrounding the publication of the manuscript reportedly written by Bozhovich in 1935 (Bozhovich, 1935) is a perfect illustration of this "retroactive impact" and of the immense complexity in reconstructing the intellectual history of this period. To the best of our knowledge, the first reference to it is found in the classic monograph published in 1964 (Zaporozhets \& El'konin, 1964) and translated into English in 1971 (Zaporozhets \& El'konin, 1964/1971). This Bozhovich work was featured in Chapter 5 of the Development of Thinking (Zaporozhets, Zinchenko, \& El'konin, 1964, 1964/1971), where it is enigmatically referred to as a study done under the supervision of Vygotsky (p. 207); a few pages later it is mentioned in the context of work completed under the guidance of Leontiev (p. 212), and yet three pages later (p. 215) Vygotsky's supervision is mentioned again (respectively, pp. 201, 217, and 220 of the English edition of 1971). Characteristically, this work of Bozhovich, actually written in 1935 and first presented to the general reader almost 30 years later, was an important contribution to Vygotskian psychology. It was clearly known to the inner circle of Vygotskian researchers - most likely also to Vygotsky himself - and it definitely affected later studies in this tradition. It was finally published in Russian in the journal Cultural-Historical Psychology more than seventy years after it was written (Bozhovich, 1935/2006a; 1935/2006b; 1935/2006c). Interestingly enough, according to Bozhovich herself, the actual study began in 1929 in Moscow, lasted for three years and was completed in Kharkov, well before Vygotsky's death in 1934. Therefore, it turns out to be one of the first Kharkov-based studies known to us that demonstrates the transition from the Moscow studies of the early 1930s to the Kharkov developments over the decade of the 1930s and beyond. 
Kharkov to Kiev in 1934, immediately following the official designation of Kiev as the capital of Soviet Ukraine; and the Kharkov branch of the Scientific Institute of Pedagogy was then reorganized into the Kharkov Institute of Pedagogy, where the Kharkov group continued their work until the end of 1936, when the Institute was finally closed down (Yarmachenko, 2001). Fifth, the notorious decree of the Communist Party on "paedological perversions" - which officially banned studies in the field of paedology (i.e. an interdisciplinary study of the child) also had a considerable negative affect on all psychological research nationwide (Joravsky, 1989). Finally, at the end of 1936 and beginning of 1937, the Ukrainian Psychoneurological Academy was renamed the Ukrainian Psychoneurological Institute (P. V. Voloshin, 1994) and its Psychological Sector significantly reduced (Haenen \& Galperin, 1989). The only unit that survived the reorganization was the Department of Clinical Psychology.

The period from 1937-1941 is distinct from the first period of the school in several ways. First, by the second half of the 1930s the Kharkov State Pedagogical Institute became the main research center of the Kharkov School and remained its head organization until the summer of 1941. Second, during this period the first regular publications of the Kharkov School appeared. Due to a significant publication backlog, both older and newer research was first published. This is also when the first scientific conferences were organized under the auspices of the Kharkov State Pedagogical Institute. Third, a new series of doctoral (candidate) studies were conducted by the students of Vygotsky's students, that is, second-generation Vygotskians (Kotlyarova, Gordon, Titarenko, Kontsevaya, Mazurenko, Aks, Voloshin, Kozis, Margolis). Fourth, the "old Vygotskians" (Leontiev, Zaporozhets, and Bozhovich) undertook advanced doctoral research projects; ${ }^{6}$ Leontiev completed his dissertation by the end of the 1930s, whereas those of Zaporozhets and Bozhovich were interrupted by the beginning of the war. ${ }^{7}$ Let us now consider these points in more detail.

\section{The Founding of the Kharkov School (the First Period of 1931-1936)}

The history of the Kharkov school of psychology starts around the end of 1931, when a group of Vygotsky's students and collaborators left Moscow for Kharkov-then capital of Soviet Ukraine - to head a major psychological research center at the newly established Ukrainian Psychoneurological Academy (UPNA). This group included Vygotsky's long-term collaborators Luria, Leontiev, and Lebedinskii ${ }^{8}$ - all three prominent scholars - as well as the younger generation of Vygotsky's students, Zaporozhets (with his wife Ginevskaya), and Bozhovich. Vygotsky's students in Kharkov were joined by local researchers Galperin, Asnin, Zinchenko, Lukov, and Khomenko, among others, who greatly contributed to the school's foundation and its original research program. As was standard practice then (and probably for financial reasons), group members held several jobs at different places simultaneously. By the end of 1933, many Vygotskian researchers had also settled into Ukrainian Scientific Institute of Pedagogy (UNDIP) (in the fall of 1932) and Kharkov State Pedagogical Institute (KDPI)

\footnotetext{
6. In the Sovet Union, the first academic degree - Candidate of Sciences (Kandidat Nauk) — is roughly equivalent to the North American degree of Doctor of Philosophy, or PhD. It was awarded upon successful completion of the candidate's dissertation. However, a second academic degree-Doctor of Sciences (Doktor Nauk) — was superior to the first and normally required a larger dissertation on a fundamental scientific topic.

7. Reportedly, Zaporozhets completed his dissertation before 1941, but did not defend it. All his prewar work, including his dissertation, perished in a building in Kharkov, destroyed during the war (Ginevskaya, 2005).

8. Luria and Leontiev both worked at UPNA, frequently commuting between Moscow and Kharkov. They came to Kharkov every month for twenty days between 1932 and 1934, when they both returned to Moscow (Luria in the spring, Leontiev in the fall of 1934). Importantly, however, even after their departure, neither lost contact with the research group in Kharkov, and from time to time they visited Kharkov. Characteristically, A. N. Leontiev refers to the "year of his work in Ukraine" as the period of 1931-1936 (A. N. Leontiev, 1999).
} 
(in the fall of 1933), both also in Kharkov. While several dissertations were completed by Kharkov school members at the UNDIP, the Ukrainian Psychoneurological Academy remained the main research center for the school until the Central Committee of the Communist Party 1936 decree on "paedological perversions."

Alexander Luria was the founder and first director of UPNA's Psychological Sector from 1931 until early 1934, when he returned to Moscow to join Medical Genetic Institute (MGI) (in October 1933) and - already after Vygotsky's death in June 1934 - the All-Union Institute of Experimental Medicine (VIEM) (in October 1934) (E. A. Luria, 1994, p. 73). After Luria, L. L. Rokhlin became the head of the Psychological Sector of UPNA (Galperin, 1934; Shmelkin, 1934; Zatonskaya, 1934). ${ }^{10}$ Vygotsky also participated in founding the Psychological Sector at UPNA in 1931-1932 and supervised research of the Kharkov group. In the very beginning of 1934, Vygotsky was involved in a very similar project: he was invited to organize a new major psychological research unit at the All-Union Institute of Experimental Medicine (VIEM) in Moscow, for him a unique "opportunity to carry out all his plans and create a well-organized team of researchers that he was dreaming about all his life and that would take the responsibility of carrying out everything the genius had in his mind" (A. R. Luria, 1935/2003). We know just a few details about the actual arrangements and can only guess what the proposed research program of this Department at VIEM might have been (Vygodskaya \& Lifanova, 1996, 1999). It is most likely that the Psychological Department at VIEM would have been organized with the Sector of Psychology at UPNA serving as a model and a prototype for the new research unit.

The earliest and fullest account of the internal structure of the Psychological Sector and the main research themes dates back to Galperin's article "Psychological Sector" in the first collection of the works of the Ukrainian Psychoneurological Academy published in 1934 as the information materials for the participants of the First All-Ukrainian Psychoneurological Conference (Galperin, 1934). In this paper, Galperin presents three main research units of UPNA's Psychological Sector as the main center of psychological activity in Ukraine at that time: (1) the Department (Otdel) of General Experimental and Genetic (i.e., Developmental) Psychology, (2) the Department of Clinical Psychology, and (3) the Department of General

9. The first attack on paedology in Ukraine took place well before the 1936 All-Union campaign against the use of tests in the Human Sciences, such as paedology or psychotechnics (i.e., applied or industrial psychology). Indeed, as Lev Kopelev noted, "In Ukraine 1937 began in 1933" (cited by Subtelny, 1988). The campaign of 1933 was clearly politically motivated and its main target was Skrypnik, the Commissar (i.e., the Minister) of Education of Ukraine and his politics of Ukrainization. Following accusations of the "nationalist deviation," "lack of vigilance," "Trotskyism," and even "fascism," Skrypnik committed suicide on 7 July 1933. Orest Subtelny points out that "the destruction of Ukrainian institutions, begun in 1930, now reached its high point”" (Subtelny, 1988, p. 419). Subsequently, leading figures in education in Ukraine in 1933-1934 were ostracized, fired, and some of them were even arrested. Most notably, the victims of this campaign were the group of scholars of the so-called "Kharkov school of pedagogy" (Sokolyanskii, Protopopov, Zaluzhnyi, Volobuev, etc.), all reflexologists and paedologists affiliated with the Ukrainian Scientific Institute of Pedagogy and Kharkiv State Pedagogical Institute (Institute of Corrective Pedagogy, 2000-2002; Ivanova, 1995; Yarmachenko, 2001). This is why the group of Vygotskian scholars, the Kharkov psychologists, explicitly distanced themselves from either paedology or pedagogy (P. I. Zinchenko, 1934) and chose Psychoneurological Academy - under the auspices of the Ukrainian Ministry of Health — as their head organization. "Thank God, we had nothing to do with Skrypnik (we were in the system of Narkomzdrav [i.e. Ministry of Health] . . .)," remarks A. N. Leontiev in his Memoirs recorded in 1976 by A. A. Leontiev (A. N. Leontiev \& Leontiev, 2005, p. 378). Two other institutions that should be mentioned in this context are the Poltava State Pedagogical Institute in Poltava, Ukraine, where Bozhovich was appointed Head of the Department and the Kharkov State Pedagogical Institute of Foreign Languages, where Zinchenko worked until the early 1960s, when it merged with the Kharkov State University. The role of these institutes in the history of the post-Vygotskian psychological research in 1930s is considerably less significant. 10. On the basis of available documents we can not confirm the claim that it was A. N. Leontiev who, "after Luria's permanent departure - took over the administration of the entire psychology division from him" (A. A. Leontiev, 2005, p. 33). 
Psychological Theory—headed by Leontiev, Lebedinskii, and Galperin, respectively. While Galperin's department was a cross-sectional unit with scholars from different fields, the other two departments were specialized units with their own distinct agendas and research teams.

According to Galperin (1934), Leontiev's Department of General Experimental and Genetic Psychology contained three psychological laboratories, each pursuing a specific research problem. The Laboratory of Animal Psychology (zoopsychology) focused on the study of instinctive behavior and skill — as opposed to cultural, mediated, distinctly human behavior. The Laboratory of Child Psychology focused on three research themes: (a) "development of thought and introspective processes in childhood"; (b) "investigation of inter-functional relations as a method of developing children's psychological characteristics"; and (c) the applied psychological research theme "the psychology of the perception (alternatively, "the psychology of osmyshlenie," perhaps best translated as understanding) of visual elements of a book by preschoolers." 11 Finally, the Laboratory of General Experimental Psychology focused on two research themes: (a) "alteration of the internal meaning of speech in its development" and (b) "forming motor skills under the conditions of higher psychological activity." A more detailed (although somewhat cryptic) account of the actual research done at UPNA's Department of General Experimental and Genetic Psychology is found in the archival materials for Leontiev's presentation at an October 12th research meeting with Vygotsky in Moscow, in 1933. ${ }^{12}$ The five research projects that Leontiev presented to Vygotsky were studies on (1) "transfer" as a means of concept formation; (2) "word origin"; (3) "speech and practical intellect"; (4) "development of reasoning"; and (5) “concept acquisition” (A. N. Leontiev, 1933/1994).

Lebedinskii's Department of Clinical Psychology studied psychological processes in patients with cortical brain lesions, primarily those with aphasia and related disorders like alexia, agraphia, and various kinds of agnosia. The central problem for this group of researchers was the role of inner speech and its loss in a wide range of cortical brain damage syndromes. This main work was accompanied by a number of supplementary and auxiliary studies on the specificity of psychological processes in clinical settings, as well as the restoration and vicarious substitution of psychological functions after brain injury. A special series of studies focused on the methodological issue of how to investigate patients with cortical brain lesions, aiming to develop new techniques and clinical approaches to replace the outdated methods of investigation widely practiced in neurological and psychiatric clinics at that time.

Luria, the founder and the first Director of UPNA's Psychological Sector, is usually only briefly mentioned in scholarly accounts of the history of the Kharkov school of psychology. However, even after his departure to Moscow in 1934, Luria was closely associated with the Kharkov group, especially with the Department of Clinical Psychology and its program of psychological research on pathology initiated by Vygotsky and Luria in the early 1930s (Zeigarnik \& Rubinshtein, 1960). The close affinity between the psychological background of the Kharkov school and Luria's "post-Kharkov" work in Moscow reveals itself in a series of studies by Lebedinskii and Luria and their collaborators on heredity and cultural environment in the development of identical twins done in the early 1930s at the Medical-Genetic Institute (Lebedinskii, 1932; A. R. Luria, 1936; A. R. Luria \& Mirenova, 1936a, 1936b)—studies that pioneered psychogenetic research in the Soviet Union (Grigorenko \& Ravich-Shcherbo, 1997).

11. This was a study on the child's perception of book illustrations done upon request from the Kharkov Institute of Polygraphy (Zaporozhets, 1981).

12. The format and historical circumstances of this meeting and who exactly participated in it besides Vygotsky and Leontiev remain unknown. 
One such study was discussed at the UPNA scientific conference on genetics and variability held in Kharkov in January 1936 (A. R. Luria, Mirenova, \& Morozova, 1936). Another of Luria's important scientific contributions was his research on the impact of cultural factors on human development conducted during his two psychological expeditions to Central Asia (Nell, 1999). These expeditions took place in the summer of 1931 (A. R. Luria, 1931a; 1931b; 1932b) and 1932 (A. R. Luria, 1933; 1934). Both expeditions were organized by local and Moscow institutions, as well as - for the second expedition-the Ukrainian Psychoneurological Academy (specifically mentioned in A. R. Luria, 1933; 1934). However, for a number of reasons, the results of these cross-cultural studies were not published for the next four decades (A. R. Luria, 1976). Unfortunately, this early psychogenetic and cultural-psychological research was abruptly halted in the1930s. Scientific discourse and the style of scientific criticism gradually changed from rational discussion of the relative strengths and weaknesses of these scientific theories to base, politically motivated, and very emotional arguments about scientists' loyalty to Communist ideas and their struggle with opportunism and with digressions from the general course of the Party and true Marxist and Communist science. ${ }^{13}$ Many promising and diverse ideas in Soviet behavioral and human sciences from the 1930s onward ended as a result of the political oppression, arrest, and even physical execution of prominent scientists of the time (Yaroshevskii, 1991). ${ }^{14}$

\section{The All-Ukrainian Scientific Institute of Pedagogy (UNDIP).}

The second largest research center of the Kharkov school of psychology, before 1936, was the All-Ukrainian Scientific Institute of Pedagogy (UNDIP). Most dissertations by younger researchers of the Kharkov school were completed and defended there in mid1930s. ${ }^{15}$ A brief report in 1934 in Komunistychna osvita ${ }^{16}$ on early research done by the "group headed by Professor Leontiev" provides an overview of a series of research projects, presumably done in fulfillment of the Candidate of Sciences degree. The overview states that

13. For examples of such academic discourse in the Soviet Union in the 1930s, see the articles by Talankin, Razmyslov, Rudneva, and others in the special issue of the Journal of Russian and East European Psychology, 38(6), 2000, on "Criticizing Vygotsky."

14. Thus, for instance, Lebedinskii's and Luria's collaborator Anna Nikitichna Mirenova was arrested in February 1945 , charged with "participation in counter-revolutionary group and terrorist intentions," sentenced in October, and executed in November of the same year (see http://lists.memo.ru/d58/f384.htm\#n27). Director of the MedicoGenetic Institute, Solomon Grigor'evich Levit was arrested in January 1938, and — on charges of espionage and participation in counter-revolutionary terrorist "saboteur-subversive" organization - sentenced and executed in May 1938 (http://lists.memo.ru/d51/f138.htm\#n19).

15. Generally, by 1936, many post-graduate dissertations had been completed by the members of the group. During this period Candidate of Sciences dissertation projects were developed by Asnin, Zaporozhets, Zinchenko, Khomenko, Lukov (UNDIP or KDPI, Kharkov, all defended in Kharkov around 1936-1937), as well as Galperin and Voloshin (UPNA/UPNI, Kharkov). Lukov defended his dissertation in Leningrad around 1939. Lebedinskii presented the material of his 1931 monograph (Lebedinskii, 1931) as the Doctor of Sciences dissertation and defended it in February 1936, at UPNA. On the basis of his 1932 monograph on affect published in English in the United States (A. R. Luria, 1932a), Luria prepared his Doctor of Sciences dissertation and defended it in Tbilisi, in 1937. Little is known about the Candidate of Sciences dissertations of Bozhovich, Mistyuk, and, possibly, Rozenblyum, also seemingly prepared during this time.

Later, in the second half of the 1930s, Doctor of Sciences dissertations were prepared by Leontiev, Zaporozhets, and Bozhovich. Leontiev's dissertation was defended in Leningrad in May 1941, while Bozhovich and Zaporozhets were interrupted by the outbreak of the war. The dissertations of Aranovskaya, as well as of younger researchers like Gordon, Kotlyarova, and Mazurenko, were completed only after the war.

16. That is, Communist Education, a rather obscure journal published in Kharkov by the Ministry of Education of the Soviet Ukraine. 
the group worked on the problem of "learning and development" and that a collected-works publication was to be submitted by 1 October, 1934 (Kolomiets', 1934). The themes developed included the problems of the child's naïve understanding and practical experience, and the problem of formal schooling (Bozhovich, Zaporozhets, Asnin, Mistyuk); the role of discourse in the classroom (Sverdlykiv'skyi, Asnin); psychological analysis of forgetting (Zinchenko); overcoming inadequate understanding in learning (Khomenko); and interest and motivation (Zaporozhets). ${ }^{17}$ However, these collected works, for some reason, were not prepared and submitted to the publisher until 1936. And soon they were afterward revoked by the authorities and banned. (Although, luckily, the galley proofs of the book have been preserved, the planned publication of these early works never took place and they still remain unpublished. $)^{18}$

\section{Kharkov School after 1936 (the Second Period of 1937-1941)}

As mentioned earlier, the decree of 1936 and the purges that it triggered had a devastating affect - not only on research in paedology or psychotechnics, but also on psychology. Very dramatic was the reorganization - rather the "devastation" (Savenko, 2003) - of the Ukrainian Psychoneurological Academy that followed its transformation into the Ukrainian Psychoneurological Institute. As a result of this reorganization all that remained of the Psychological Sector was the group of psychologists affiliated with the Department of Clinical Psychology, renamed into Laboratory of Clinical Psychology. The Departments of Genetic Psychology and General Psychological Theory were closed down (Haenen \& Galperin, 1989; Naiman, Yudin, \& Vol'fovskii, 1940); and the other members of the larger research team were dismissed by the end of 1936 .

The campaign of 1936 had direct impact on the lives and academic careers of the early generation of Vygotskian scholars. By the end of 1936, Luria had quit all the institutions he had worked for and transferred to full-time studies at the Medical Institute in Moscow-an action probably instrumental in saving his life (E. A. Luria, 1994). Meanwhile, Leontiev had been dismissed from all his academic and research positions and remained unemployed for a while (A. A. Leontiev, Leontiev, \& Sokolova, 2005). Philip Bassin resigned from UPNA and left Kharkov for Moscow in 1936 (Savenko, 2005, 2006). Alexander Zaporozhets was detained and interrogated by the NKVD (precursor of KGB) authorities not less than six times on charges of "anti-Soviet activity," but was eventually-miraculously-released (Ginevskaya, 2005). Another painful loss for the group was Anatolii Rozenblyum, who was

17. The actual titles of these works are "The Role of Scientific Verbal Formulations in School Knowledge Acquisition" (Asnin); "Naïve Experience of a Child and School Knowledge Acquisition” (Bozhovich); "Connecting Theoretical Knowledge with a Child's Practice as the Problem of Developing Interest" (Zaporozhchenko [sic]); "A Psychological Analysis of Forgetting" (Zinchenko); "School Laboratory Work Experiments and Their Role in Knowledge Acquisition" (Mistyuk); "The Child's Discourse and the Teacher" (Sverdlykivs'kyj); "The Psychology of Overcoming Children's Inadequate Understanding of School Topics" (Khomenko).

18. The only exception is Leontiev's article, "The Assimilation of Scientific Concepts by Schoolchildren," (A. N. Leontiev, 1936/1983; 1936/1995) that was to be included in the collective monograph. The juxtaposition of the titles of these two unpublished books suggests that this might be the very same collection of works announced in the research overview by UNDIP in October 1934. The other papers included in this unpublished 1936 volume were (1) "Life Experience of the Child and School Knowledge" (Bozhovich); (2) "The Study of Denominating Using the Method of Transfer" (Asnin); (3) "The Fate of Scientific Notions Acquired at School" (Zinchenko); (4) “Comparative Investigation of 'Experimental Notions' and the Notions Acquired at School” (Khomenko); (5) "The Role of Visuals in School Knowledge Acquisition" (Mistyuk); and (6) "Semantic Analysis of the Meanings of the Words Learned at School" (Asnin \& Zaporozhets). 
arrested around 1937 and perished (Noskova, 1997, 2005; V. P. Zinchenko \& Morgunov, 1994). ${ }^{19}$

It is sometimes claimed that the decree of 1936 against paedology "led to the end of the Kharkov school" (Haenen, 1996, p. 38) and, at first glance, the group does seem to disappear from public academic life from 1936-1937. We find virtually no trace of the Kharkov School in an overview of Russian psychological research done in 1938-1939 (Rybnikov, 1940). However, we hope to show that researchers at the Kharkov school continued their work throughout the entire decade of the 1930s until the beginning of the war in 1941. In fact, the second half of this decade was a very productive period of scientific research for the Kharkov School, one that resulted in important new scientific insights. The most important studies of this period were done under the auspices of the Kharkov State Pedagogical Institute (KDPI), which gradually became the main research center of the school. The first KDPI scientific conference (Scientific Session) was held in 1938, launching a series of such conferences that were major scientific events. Specifically, the KDPI Scientific Sessions in 1940 and 1941, as well as the Conference on Pedagogy and Psychology held in Kiev in 1940, generated several publications that show the wide range of studies done at the Kharkov school. ${ }^{20}$ In fact, the research of the Kharkov school that was published between 1939 and 1941 represents all the main trajectories of empirical work at the school, including work done before 1936. These studies are reviewed in the next section.

\section{Vygotsky’s Psychology and the Kharkov School: Research Overview}

\section{Vygotsky's Psychological Theory and Empirical Research in Kharkov}

Our discussion of the Kharkov school would be incomplete without mentioning Vygotsky's inspiration. In fact, the studies done in Kharkov in the 1930s only make sense from the perspective of the research program introduced by Vygotsky. Likewise, we argue that Vygotskian psychology cannot be completely understood without knowing how it developed through the early work of Vygotsky's students and collaborators.

In fact, Vygotsky was in close contact with the Kharkovites in the early 1930s, and visited both Kharkov and nearby Poltava several times to meet Bozhovich and the main group from Kharkov. Vygotsky even studied at the Medical Department of the UPNA in the early 1930s and occasionally lectured in Kharkov (Ginevskaya, 2005; Vygodskaya \& Lifanova,

19. In our effort to investigate the fate of Anatolii Rozenblyum, we came across an extremely valuable resource published online by the International Historical-Enlightment Human Rights and Humanitarian Society Memorial (http://www.memo.ru/eng/), "The Victims of Political Terror in the USSR" (http://lists.memo.ru/), which presents information on more than 1.3 million victims of political purges ("cleansings") in Stalin's Soviet Union. According to the source, Rozenblyum Anatolij Il'ich, a psychologist from Kharkov employed by Poltava State Pedagogical Institute, was arrested on 29 January, 1938, charged with "active participation in anti-Soviet socialist-revolutionary [i.e., one of the two leftist political parties that survived the Socialist Revolution in Russia in 1917] terrorist organization," and convicted and executed on the same day of 22 September, 1938, in Kiev, Ukraine (http://lists.memo.ru/d73/f331.htm\#n3). Despite the differences in the patronymic name of Anatolii Rozenblyum in different accounts-Anatolii Iosifovich (Noskova, 1997, 2005) versus Anatolii Il'ich (http://lists.memo.ru/ d73/f331.htm\#n3) - we have all reason to believe that this is the same person. According to an alternative account, Anatolii Rozenblyum died of mushroom poisoning (A. A. Leontiev, Leontiev, \& Sokolova, 2005), which seems to be a mistake.

20. Most notable are the collections of scientific papers published as Scientific Notes of the Kharkov State Pedagogical Institute (Vol. 1, 1939, and Vol. 6, 1941), Scientific Notes of the Kharkov State Pedagogical Institute of Foreign Languages (1939), and Scientific Works of the All-Republican Scientific Conference on Pedagogy and Psychology in Kiev (1941). In addition, we discovered unique full-text archival materials of the first KDPI Conference of 1938 that have not yet been published. 
1996, 1999). The Kharkov group also held a series of research meetings with Vygotsky. For instance, we know that one such meeting - known as an "internal conference" - was held in the winter of 1932-1933, where Vygotsky reportedly gave an eight-hour presentation on current problems for cultural-historical psychology. ${ }^{21}$ During another important research meeting with Vygotsky that took place in October of 1933, Leontiev presented results of the studies he directed at the Department of Genetic Psychology of UPNA (A. N. Leontiev, 1933/1994). Finally, the last work published by Vygotsky in his lifetime was his presentation at the First All-Ukrainian Psychoneurological Conference held in Kharkov during the summer of 1934. Deathly ill, Vygotsky never presented the paper itself, so a full-text article was published in the volume of the Conference abstracts (Vygotsky, 1934a; 1934/1960b; 1934/1997). ${ }^{22}$

Likewise, the Kharkov School's empirical studies are fundamentally grounded in the Vygotskian research program and their common root in Vygotsky's cultural-historical psychology of higher mental functions is apparent. Thus, for instance, by the summer of 1934, representatives of all three departments of UPNA's Psychological Sector shared the assumption that "formation of higher intellectual forms of psychological activity over the course of the history of society is decisive for psychological development" (Galperin, 1934, p. 34). At the Department of General Theory of Psychology of UPNA the interrelations between psychology and physiology and the place of psychology among other Human Sciences, the development and degradation of higher mental functions, and the methodology of distinctly psychological research were all investigated. This work resulted in a number of theoretical papers written by the members of the School that still need to be assessed in relation to Vygotsky's theory (Asnin, 1938, 1941a/1980, 1941a/1981; Galperin, 1935; Lebedinskii, 1938c; A. N. Leontiev, 1940-1941/1994).

For Vygotsky, studying human mental life scientifically meant studying its historical development. Vygotsky's entire research program aimed to investigate the development of culturally mediated, or "higher," mental functions. Vygotsky and his collaborators emphasized three main lines of development, namely: (1) the evolutionary development of Homo sapiens as a biological species, (2) the historical development of modern, cultural man, and (3) the ontogenetic development of a human child into an adult (Vygotsky \& Luria, 1930). As a product of all three lines of development, cultural man "may be understood and explained scientifically only by analyzing the three different paths that make up the history of human behavior" (Vygotsky \& Luria, 1930/1993, p. 36). Another important principle of Vygotsky's psychology that was first introduced in the end of 1930 was the requirement for the two parallel lines of research: the study of normal development was complemented by the investigations of degradation and decomposition of higher mental functions, most often in clinical settings (Vygotsky, 1930/1982, 1930/1997). The most concise formulation of this fundamental principle of Vygotskian theory can be found in Vygotsky's last presentation "on development and degradation of higher mental functions," delivered on 28 April, 1934, at the conference of the All-Union Institute of Experimental Medicine in Moscow, a month and a half before his death (Vygotsky, 1934/1960a).

Thus, the program of Vygotsky's psychological research was extremely broad, covering normal human development and developmental pathology and decline. There is no agreement

21. Some fragments related to the discussion of the problem of consciousness in psychology were later published based on Leontiev's and Zaporozhets' notes as "Problem of Consciousness" (Vygotsky, 1932/1968). For some reason, a later edition dates this text as a presentation of the winter of 1933-1934 (Vygotsky, 1933/1982), and special investigation is needed to determine the exact date when this important meeting took place.

22. Vygotsky was hospitalized on 9 May and died a month later on 11 June, 1934 (Vygodskaya \& Lifanova, 1996, 1999). 
about the overall assessment of the scientific contribution of the larger Vygotsky School, and heated debates about Vygotsky's legacy still continue. In scholarly literature on Vygotskian psychology there are at least three conflicting perspectives on the role that Vygotsky's students played in Vygotskian research program development: (1) Every single idea of Vygotsky was developed by his students; (2) Vygotsky's students distorted his cultural-historical psychological theory in their work on so-called activity theory, or, more precisely, the activity approach in psychology; and (3) both cultural-historical and activity approach constitute two complementary paradigms within the larger Vygotsky School. Typically, interrelations between Vygotsky's cultural-historical theory and Leontiev's activity-oriented psychology are the focus of the numerous discussions of scientific legacy of Vygotsky. In contrast, we suggest that investigation of the many and diverse ways Vygotsky's thought was developed in his students' work in a wide range of contexts will provide a much richer account of the history of psychology and of the heuristic potential of Vygotsky's theory. Our overview of the work done by the Kharkov group hopes to advance the discussion of the fundamental issues of Vygotskian theory and how it was developed and still can be developed today.

According to Galperin (1934), experimental research in UPNA's Psychological Sector had two major goals: First, the study of human thinking, speech, and practical activityincluding their interrelations and relations to other psychological functions at different stages of human development, carried out at the Department of the General and Genetic Psychology; second, analysis of the degeneration of distinctly human higher mental functions caused by organic or functional damage to the human brain, carried out at the Department of Clinical Psychology.

\section{Developmental and General Psychology: "Ape" and "Primitive"}

As already mentioned, the Department of the General and Genetic Psychology experimentally investigated all the three lines of development important to Vygotsky. The triad of "ape, primitive, and child" (Vygotsky \& Luria, 1930; 1930/1993) was mirrored in the three Laboratories of Animal, General, and Child experimental psychology (Galperin, 1934). Thus, experimental research on the psychology of underdeveloped rural population of Uzbekistan conducted by Luria in his two Central Asian expeditions (A. R. Luria, 1931a; 1932b; 1933; 1934; 1976) aimed at experimental research on "primitive" people under the conditions of rapidly changing social environment. This research was received very negatively by officials in the Soviet Union in the early 1930s and, as a result, Luria's academic career, his freedom, and even his life, were threatened - which may explain his move to the Ukrainian Psychoneurological Academy by the end of 1931 (E. A. Luria, 1994). For political reasons, the research on "primitive" people in Vygotskian cultural-historical psychology was put on hold for several decades until the studies of Luria's students Tulviste and-in the United States-Cole (Cole, Gay, Glick, \& Sharp, 1971; Cole \& Means, 1981; Cole \& Scribner, 1974; Tulviste, 1991).

However, the other two main lines of Vygotskian developmental research remained in relatively better standing with official Marxist science of that time, and a number of studies on animal and child psychology were conducted by the Kharkov researchers in the 1930s. With minor exceptions (Zaporozhets, 1941c) most of the psychological studies by Zaporozhets, Dimanshtein, Solomakha, and Bassin on sensation and perception in animals done under Leontiev's supervision were published by A. N. Leontiev in his doctoral dissertation, prepared by 1939 and defended in May of 1941 in Leningrad. An offshoot of these studies with animals was experimental investigation of sensation formation and development in adults that was carried out by Leontiev and his collaborators - in consultation with P. P. Blonskii, 
A. I. Bogoslovskii, and M. S. Lebedinskii-in Kharkov (Asnin, Zaporozhets, Drobantseva) and Moscow (Poznanskaya, S. Ya. Rubinshtein) (Asnin, 1940; A. N. Leontiev, 1940, 1940/1981a, 1940/1981b, 1940/1981c; Zaporozhets, 1941a, 1941a/1980, 1941a/1986a). According to Leontiev's plan, sketched around 1940, all these studies were part of a major research project that was to continue until 1948-1949. The results of these studies were to be published as a monumental three-volume monograph on "the development of the psyche (mind)" that Leontiev had already partly completed by 1941 . Unfortunately, the unpublished materials perished during the war (A. A. Leontiev, Leontiev, \& Sokolova, 2005). These lost manuscripts were never restored and only a very brief summary of this project was published after the war (A. N. Leontiev, 1947, 1947/1981a, 1947/1981b).

\section{Developmental and General Psychology: "Child"}

As in America and Europe, methods of psychological research on animals made their way into the research on child psychology done in Kharkov. The experiments of Wolfgang Köhler on the "practical intelligence" of apes (Köhler, 1921; 1921/1926) triggered a series of studies of children's practical intelligence and tool-mediated practical action; these studies showed qualitative differences between the ape's and the child's use of use of auxiliary tools and instruments (Asnin, 1941a, 1941a/1980, 1941a/1981; Bozhovich, 1935, 1935/2006a, 1935/2006b, 1935/2006c; Galperin, 1937, 1937/1980; Zaporozhets, 1936, 1938a, 1938a/1986, 1939a, 1939a/1986).

Experimental studies in the fields of child and general psychology made up a considerable part of research at the Department of General Experimental and Genetic Psychology of UPNA. Within this broad topic, Vygotsky's students in Kharkov focused on investigating mediated, or "higher" mental functions - especially their genesis, structure, and interrelations (Vygotsky, 1931/1960; 1931/1998). In addition to studies on children's practical intellect, several studies were conducted on thinking, including (1) a post-Piagetian study of children's reasoning (Zaporozhets, 1942; Zaporozhets \& Lukov, 1941; Zaporozhets \& Lukov, 1941/1980, 1941/2002), (2) "transfer" mechanisms in thought development (Asnin, 1936, 1941b, 1941b/ 1980; A. N. Leontiev, 1933/1994), (3) the effect of formal schooling on children's worldviews (Bozhovich, 1936, 1937, 1945, 1945/1980; Bozhovich \& Zinchenko, 1941, 1941/1980), and (4) the development of children's visual-operational and visual-imagic thought (Asnin, 1941b/1980; Khomenko, 1941b, 1941b/1980).

A separate series of studies was conducted on the age-related characteristics of (1) voluntary and involuntary remembering in children and adults (Galperin, 1938; P. I. Zinchenko, 1936, 1937, 1939/1983, 1939a, 1939b, 1939b/1980, 1941), (2) the psychology of motion (Asnin, 1939, 1941b, 1941b/1980; Galperin, 1937, 1937/1980; Kotlyarova, 1946), and (3) the development of perception (Ginevskaya, 1941; Gordon, 1941; Khomenko, 1939; Kotlyarova, 1940, 1946; Mistyuk, 1941; Zaporozhets, 1940, 1941a, 1941a/1980, 1941a/1986b)—specifically, the perception of art by children (Aranovskaya, 1940, 1945; Khomenko, 1938, 1940, 1941a, 1941c, 1941c/1980; Kontsevaya, 1941; Titarenko, 1941; Zaporozhets, 1948, 1949, 1949/1986).

Another of Vygotsky's essential contributions to developmental psychology was his work on the role of play (Vygotsky, 1933/1966; 1933/1967) and learning (Vygotsky, 1935a; 1935c) in human development. This line of research remained largely underdeveloped in Vygotsky's own writings and is a facet of his theory most clearly articulated through collaborative work of his students. The Kharkov group focused mainly upon studies within lab settings (for discussion, see Asnin, 1941a; 1941a/1980; 1941a/1981) as well as natural settings of children's play and learning environments. A wide range of the studies on learning were conducted by Vygotsky's students at the Ukrainian Scientific Institute of Pedagogy and at the Pedagogical 
Institutes of Kharkov, Poltava, and Leningrad (Asnin \& Zaporozhets, 1936; Bozhovich, 1936, 1937, 1941, 1945, 1945/1980; Bozhovich \& Zinchenko, 1941, 1941/1980; Elkonin, 1940, 1940/1980; A. N. Leontiev, 1947/1983, 1947a, 1947a/1978; Mazurenko, 1941). The role of children's play on their development was also investigated by Vygotsky's students in Kharkov and Leningrad (Elkonin, 1978/2005; Fradkina, 1945; A. N. Leontiev, 1944, 1945; Lukov, 1937, 1938, 1939). Finally, a series of classical postwar studies continued this early research on psychological environments and their effects on children's affect, motivation, and cognition (Istomina, 1948a, 1948b, 1948/1975, 1948/1977; Manuilenko, 1948/1975).

Another remarkable development of Vygotsky's theory by his students in the late 1930s was their increasing interest in the unconscious and their research on ustanovka (what in German is called Einstellung, or in English, "set" or "attitude")—a term they most probably borrowed from the Georgian school of Dimitry Uznadze (Piaget \& Lambercier, 1944; Uznadze, 1939, 1966). Several studies of "set" were published (Aks, 1941; Galperin, 1941a, 1941a/1980, 1941b), and the major unpublished work on ustanovka by Bassinreportedly written by 1944 (Savenko, 2006) —was probably an important landmark in the long standing interest in the unconscious as understood within the context of the Vygotskian paradigm (Bassin, 1968, 1969, 1978). Indeed, the unconscious as an integral part of cultural historical and activity-oriented psychology still needs its own proper and detailed investigation.

\section{Clinical Psychology and the Study of Pathology}

The history and the work of UPNA's Department of Clinical Psychology and related clinical research done in the 1930s is the least explored connection to Vygotsky in contemporary writings, and an unwritten chapter in the history of the Kharkov school. Vygotsky himself was interested in the pathology of development from the earliest stage of his scientific career. In 1924, he defined his scientific and professional credo as "educating blind-deaf-mute children" (Vygodskaya \& Lifanova, 1996; 1999), an interest he subsequently developed in his work. Vygotsky's main research on the pathology of development and on clinical psychology were studies of aphasia and of dementias like Parkinson's or Pick's diseases (Samukhin, Birenbaum, \& Vygotsky, 1934; Vygotsky, 1935b, 1935/1956, 1935/1983), schizophrenia (Vygotsky, 1932; 1932/1956; 1933; 1934b; 1934/1994), or the localization of brain functions (Vygotsky, 1934a; 1934/1960b).

In particular, the role of language in human development was investigated through clinical cases of speech pathology - specifically, aphasia (Galperin \& Golubeva, 1933; Kozis, 1934; Lebedinskii, 1933b, 1934, 1936b, 1941; Lebedinsky, 1936; A. R. Luria, 1932/1933, 1940, 1943, 1947, 1947/1970). These studies, and Vygotsky's later work on the localization of brain functions (Vygotsky, 1934a), significantly contributed to Luria's neuropsychology (A. R. Luria, 1966). Vygotsky's study on schizophrenia was developed through several studies of concept formation (Bassin, 1938), action structure (Lebedinskii, 1940; Lebedinskii, Artyukh, \& Voloshin, 1938, 1938/1939; Zaporozhets, 1939b) and speech disorders in schizophrenia (Bassin, 1938; Lebedinskii, 1938b; Tatarenko, 1938).

The research of clinical psychologists at the Kharkov school in the 1930s was closely related to work done simultaneously in Moscow by another large group of Vygotsky's students at the All-Union Institute of Experimental Medicine (VIEM), the Experimental Defectological Institute (EDI) and several other educational and research organizations studying developmental psychology (Morozova, 1947; Shif, 1935, 1944; L. S. Slavina, 1944, 1947) and abnormal development, or defectology (Boskis, 1939; Levina, 1936, 1940; Morozova, 1944; Pevzner, 1941; Pevzner, Zankov, \& Shmidt, 1933; Zankov, 1935; Zankov \& Solov'ev, 1940). 
Indeed, in parallel with this work in Kharkov, another important group of Vygotsky's students in Moscow continued the studies he had initiated in clinical and pathological psychology (Birenbaum, 1934; Birenbaum \& Zeigarnik, 1935; Dubinin \& Zeigarnik, 1940; Kaganovskaya \& Zeigarnik, 1935; Samukhin, 1935; Samukhin, Birenbaum, \& Vygotsky, 1934; Zeigarnik, 1934, 1940, 1941; Zeigarnik \& Birenbaum, 1935). These studies led to wartime efforts in several military hospitals to restore motion and higher mental functions, under the supervision of Luria (Galperin, 1943; Galperin \& Ginevskaya, 1947; A. N. Leontiev \& Ginevskaya, 1947; A. N. Leontiev \& Zaporozhets, 1945; A. R. Luria, 1947, 1947/1970). However, a detailed investigation of the studies done by this larger circle of Vygotsky's followers not associated with the Kharkov school is beyond the scope of our paper.

\section{EPILOGUE}

Our overview of the history of the Kharkov school ends in 1941, with the beginning of German military action on the territory of the USSR. However, the development of Vygotsky's theory did not stop with the war. After the war, Vygotsky's psychological theory developed in a number of directions. The most well known was "activity theory," typically associated with Vygotsky's older contemporary and opponent, S. L. Rubinshtein, and with Vygotsky's student and collaborator, A N. Leontiev. However, within the activity-oriented school there are actually several distinctive lines of research, including (1) Galperin's stepwise model of forming mental actions (Arievitch \& Stetsenko, 2000; Arievitch \& van der Veer, 1995, 2004; Haenen, 1996), (2) research on perception and motor skills development by Zaporozhets and his associates (Venger, 1994), and (3) studies on play and learning activity by Elkonin, Davydov, and their collaborators in several research centers across the former Soviet Union (Davydov, 1996, 2004; Elkonin, 1989b; Repkin, 1997/2003a, 1997/2003b; Repkin \& Repkina, 1997).

The largest group of Vygotsky's followers in the Soviet Union developed his theory under the banner of "activity theory." Indeed, V. Zinchenko (1996) describes this phenomenon as a "strange situation," when "the authors of studies carried out in strict correspondence with the conceptual framework of cultural-historical psychology, and using a causal genetic method, interpreted the results in terms of the psychological theory of activity" (V. P. Zinchenko, 1996/2001, p. 51-52). Furthermore, he adds that "Zaporozhets, Lisina, Leont'ev, and later many others (whether or not consciously and intentionally) carried out studies that might have been conceived by Vygotsky in that they departed from the classical oppositions of subjective vs. objective, the material vs. the ideal, and discovered a new ontology for psychology" (V. P. Zinchenko, 1996/2001, p. 52).

But although several activity-oriented versions of Vygotsky's psychology were developed, much of the research done in the Vygotskian tradition seems to have bypassed the activity-oriented framework. For instance, neither Luria nor any of his associates working on neuropsychological problems aligned themselves with the activity approach (Brushlinskii, 1998); instead, they continued to develop Vygotsky's ideas on the role of language in human development, and on the affective-semantic and dynamic structure of consciousness. These Vygotskians were instrumental in establishing neuropsychology as a field of scientific research (Akhutina, 1996, 1996/2003; Homskaya, 1992/2001); other lines of research in medical and pathological psychology associated with Vygotsky's followers were influenced by-yet remain parallel to - the activity-oriented framework (Lebedinskii \& Myasishchev, 1966; Zeigarnik, 1962, 1962/1965, 1986). Finally, L. Bozhovich's research group explored problems of personality development in children (Bozhovich, 1968; Bozhovich \& 
Blagonadezhina, 1961, 1972; L. I. Slavina, 1958, 1966) and expressed explicit critique of the some of the activity theory claims.

Following Akhutina (2004), we believe that Vygotsky's overall scientific project can only be understood as spanning the two complementary lines of inquiry from both the culturalhistorical and natural-scientific perspectives. In this light, it is remarkable to consider how all these different psychological schools, despite their differences, fall under the broad framework laid down by Vygotsky. The flexibility, breadth, and heuristic potential of Vygotsky's theorizing seem particularly important today, given that the fragmentation of science is increasingly acknowledged as an acute problem. Our study of the Kharkov school is a first step toward a historical analysis that hopes to reconstruct Vygotsky's integrative research program - but a lot of work remains to be done.

\section{ACKNOWLEDGEMENTS}

This work was partially supported by grants from the Social Sciences and Humanities Research Council of Canada (SSHRC) and the Canadian Institute of Ukrainian Studies (CIUS) Exchanges with Ukraine Endowment Fund of the University of Alberta, Canada. We also want to express our gratitude to Dr. Ivan Fedorovych Prokopenko, Rector of Skovoroda Kharkiv National Pedagogical University, and Dr. Petro Vlasovych Voloshyn, Director of the Institute of Neurology, Psychiatry, and Narcology of the Academy of Medical Sciences of Ukraine, for their interest in this project and permission to use unique library and archival materials.

\section{REFERENCES}

Akhutina, T. V. (1996). L. S. Vygotskii i A. R. Lurija: Stanovlenie nejropsikhologii [L. S. Vygotsky and A. R. Luria: Development of neuropsychology]. Voprosy psikhologii, 5.

Akhutina, T. V. (1996/2003). L. S. Vygotsky and A. R. Luria: Foundations of neuropsychology. Journal of Russian and East European Psychology, 41, 159-190.

Akhutina, T. V. (2004). L. S. Vygotskii: Kul'turno-istoricheskij i estestvenno-nauchnyj podkhody k interiorizatsii [L.S. Vygotsky: Cultural-historical and natural-scientific approaches to internalization]. Vestnik MGU. Serija 14. Psikhologiya, 3, 41-56.

Aks, O. M. (1941). Do pytannya utvorennya sensornoji ustanovky [To the issue of sensory set formation]. In Naukova sesiya KhDPI. Kharkov.

Aranovskaya-Dubovis, D. M., \& Zaika, E. V. (1995). Idei A. V. Zaporozhtsa o razvitii lichnosti doshkol'nika [A. V. Zaporozhets' ideas on personality development in the preschooler]. Voprosy psikhologi, 5, 87-99.

Aranovskaya, D. M. (1940). Zavisimost' ponimaniya rebenkom skazki ot ee kompozitsii [Effect of a fairy-tale structure on its understanding by a child]. In Naukova sesiya KhDPI. Kharkov.

Aranovskaya, D. M. (1945). Zavisimost' ponimaniya rebenkom skazki ot ee kompozitsii [Effect of a fairy-tale structure on its understanding by a child]. Unpublished Kandidate dissertation, Kharkov.

Arievitch, I., \& Stetsenko, A. (2000). The quality of cultural tools and cognitive development: Gal'perin's perspective and its implications. Human Development, 43, 69-92.

Arievitch, I., \& van der Veer, R. (1995). Furthering the internalization debate: Gal'perin's contribution. Human Development, 38, 113-126.

Arievitch, I., \& van der Veer, R. (2004). The role of nonautomatic processes in activity regulation: From Lipps to Galperin. History of Psychology, 7, 154-182.

Asnin, V. I. (1936). Issledovanie oboznacheniya metodom perenosa. Unpublished collection of the Kharkov school works.

Asnin, V. I. (1938). K voprosu ob usloviyakh nadezhnosti psikhologicheskogo issledovaniya intellekta [To the problem of the conditions of reliability of psychological investigation of intellect]. Paper presented at the Tezisy dokladov nauchnoj sessii Khar'kovskogo gosudarstvennogo pedagogicheskogo instituta, Kharkov.

Asnin, V. I. (1939). Svoeridnist' rukhovykh navychok zalezhno vid umov jikh tvorennya [Characteristics of motion skills depending on the conditions of their formation]. In Naukovi zapysky Kharkivs'kogo derzhavnogo pedagogichnogo instytutu (Vol. 1, pp. 37-65). Kharkov.

Asnin, V. I. (1940). Ob usloviyakh vozniknoveniya oshchushcheniya [On the conditions of the origin of sensation]. In Naukova sesiya KhDPI (p. 27). Kharkov. 
Asnin, V. I. (1941a). Pro umovy nadijnosti psykhologichnogo eksperymentu [On the conditions for the reliability of psychological experiment]. In Naukovi zapysky KhDPI (Vol. 6). Kharkov.

Asnin, V. I. (1941a/1980). Ob usloviyakh nadyozhnosti psikhologicheskogo eksperimenta. In I. I. Ilyasov \& V. Y. Lyaudis (Eds.), Khrestomatiya po vozrastnoi i pedagogicheskoi psikhologii (Vol. 1. Raboty sovetskikh avtorov perioda 1918-1945 gg.). Moscow: MGU.

Asnin, V. I. (1941a/1981). The conditions for reliability of a psychological experiment. Soviet Psychology, 19, 80-99.

Asnin, V. I. (1941b). Pro pozvytok naochno-diyovogo myslennya u dytyny. In Pratsi respublikans'koji naukovoji konferentsiji z pedagogiky i psykhologiji (Vol. 2. Psykhologiya).

Asnin, V. I. (1941b/1980). The development of visual-operational thinking in children. Soviet psychology, 18, $23-36$.

Asnin, V. I., \& Zaporozhets, A. V. (1936). Semicheskij analiz yazykovykh znachenij, usvoennykh v shkole. Unpublished collection of the Kharkov school works.

Bakhurst, D. (1990). Social memory in Soviet thought. In D. Middleton \& D. Edwards (Eds.), Collective remembering (pp. 203-226). London: Sage.

Bassin, F. V. (1938). Narushenie znacheniya slov pri shizofrenii [Words meanings alteration in schizophrenia]. Unpublished Candidate of Sciences dissertation, UPNI, Kharkov.

Bassin, F. V. (1968). Problemy bessoznatel'nogo (o neosoznavaemykh formakh vsshej nervnoj deyatel'nosti) [The problems of the unconscious (on the uncognized forms of the higher nervous activity)]. Moscow: Meditsina.

Bassin, F. V. (1969). Consciousness and the unconscious. In M. Cole \& I. Maltzman (Eds.), A handbook of contemporary Soviet psychology (pp. 399-420). New York: Plenum Press.

Bassin, F. V. (1978). U predelov raspoznannogo: k probleme predrechevoj formy myshleniya [At the borders of the cognized: To the problem of pre-speech form of thinking]. In A. S. Prangishvili, A. E., Sherozia, \& F. V. Bassin (Eds.), Bessoznatel'noe. Priroda, funktcii, metody issledovaniya (Vol. 3, pp. 735-750). Tbilisi: Metsniereba.

Birenbaum, G. V. (1934). K voprosu ob obrazovanii perenosnykh i uslovnykh znachenij slova pri patologicheskikh izmeneniyakh myshleniya [To the issue of figurative and conditional words meanings in cases of pathological alterations of thought]. In Novoe $v$ uchenii ob agnozii, apraksii i afazii. Moscow: OGIZ.

Birenbaum, G. V., \& Zeigarnik, B. V. (1935). K dinamicheskomu analizu rasstrojstv myshleniya [To dynamic analysis of mental diseases]. Sovetskaya nevropatologiya, psikhiatriya i psikhogigiena, 4.

Bocharova, S. P. (1978). Problemy psikhologii pamyati v trudakh P. I. Zinchenko [Problems of the psychology of memory in the works of P. I. Zinchenko]. Voprosy psikhologi, 5.

Bocharova, S. P. (1978/1979). Problems of the psychology of memory in the works of P. I. Zinchenko. Soviet Psychology, 17, 104-113.

Boskis, R. M. (1939). O razvitii slovesnoj rechi glukhonemogo rebjonka [On the development of verbal speech of the deaf-mute child]. Moscow: Uchpedgiz.

Bozhovich, L. I. (1935). Rech' i prakticheskaya intellektual'naya deyatel'nost' [Speech and practical intellectual activity]. Unpublished manuscript.

Bozhovich, L. I. (1935/2006a). Rech' i prakticheskaya intellektual'naya deyatel'nost' rebyonka (eksperimental'nopsikhologicheksoe issledovanie) [Speech and practical intellectual activity of a child. (An experimental-theoretical study) (part 1)]. Kul'turmno-istoricheskaya psikhologiya, 1.

Bozhovich, L. I. (1935/2006b). Rech' i prakticheskaya intellektual'naya deyatel'nost' rebyonka (eksperimental'nopsikhologicheksoe issledovanie) [Speech and practical intellectual activity of a child. (An experimental-theoretical study) (part 2 \& 3)]. Kul'turmno-istoricheskaya psikhologiya, 2.

Bozhovich, L. I. (1935/2006c). Rech' i prakticheskaya intellektual'naya deyatel'nost' rebyonka (eksperimental'nopsikhologicheksoe issledovanie) [Speech and practical intellectual activity of a child. (An experimental-theoretical study) (part 4)]. Kul'turmno-istoricheskaya psikhologiya, 3.

Bozhovich, L. I. (1936). Zhiznennyj opyt rebyonka i shkol'nye znaniya [Life experience of the child and school knowledge]. Unpublished collection of the Kharkov school works.

Bozhovich, L. I. (1937). Psikhologiya upotrebleniya pravila na bezudarnye soglasnye kornya [Psychology of the application of the orthographical rule on the unstressed vowels in the root of a word spelling]. Sovetskaya pedagogika, 5-6.

Bozhovich, L. I. (1941). Rol' punktuatsii v ponimanii pis'mennoj rechi. In Naukova sesiya KhDPI (pp. 39-40). Kharkov.

Bozhovich, L. I. (1945). O psikhologicheskoj prirode formalizma shkol'nykh znanij [On the psychological nature of the formalism of the school knowledge]. Sovetskaya pedagogika, 9.

Bozhovich, L. I. (1945/1980). Psikhologicheskij analiz formalizma v usvoenii shkol'nykh znanij [Psychological analsis of the formalism in the acquisition of school knowledge]. In I. I. Ilyasov \& V. Y. Lyaudis (Eds.), Khrestomatiya po vozrastnoi i pedagogicheskoi psikhologii (Vol. 1, Raboty sovetskikh avtorov perioda 1918-1945 gg.). Moscow: MGU.

Bozhovich, L. I. (1968). Lichnost' i ee formirovanie v detskom vozraste [Personality and its formation in children]. Moscow: Prosveshchenie.

Bozhovich, L. I. (1995). Problemy formirovaniya lichnosti [The problems of personality development]. Moscow: Institut prakticheskoi psikhologii.

Bozhovich, L. I., \& Blagonadezhina, L. V. (Eds.). (1961). Voprosy psikhologii lichnosti shkol'nika [The issues of the psychology of personality of the schoolchild]. Moscow: APN. 
Bozhovich, L. I., \& Blagonadezhina, L. V. (Eds.). (1972). Izuchenie motivatsii povedeniya detej i podrostkov [Investigations on the motivation of the behavior of children and adolescents]. Moscow: Pedagogika.

Bozhovich, L. I., \& Zinchenko, P. I. (1941). Pro psykhologiyu zasvoennya znan' uchnyamy [On the psychology of knowledge acquisition by students]. In Pratsi respublikans'koji naukovoji konferentsii z pedagogiky i psykhologiji (Vol. 2. Psykhologiya).

Bozhovich, L. I., \& Zinchenko, P. I. (1941/1980). The psychology of acquiring factual knowledge by schoolchildren. Soviet Psychology, 18, 67-83.

Brushlinskii, A. V. (1998). Razrabatyval li A.R. Lurija problemu deyatel'nosti? [Did A. R. Luria develop the problem of activity?]. Paper presented at the I International conference in memory of A. R. Luria, Moscow.

Cole, M. (1977). Introduction. In A.V. Zaporozhets, The development of logical thinking in the preschool-age child. Soviet psychology, 15, 45-46.

Cole, M. (1979). Epilogue: A Portrait of Luria. In A. R. Luria (Ed.), The making of mind. A personal account of Soviet psychology (pp. 189-225). Cambridge, MA: Harvard University Press.

Cole, M. (1980). Introduction: The Kharkov school of developmental psychology. Soviet psychology, 18, 3-8.

Cole, M., Gay, J., Glick, J., \& Sharp, D. (1971). The cultural context of learning and thinking. New York, NY: Basic Books.

Cole, M., \& Levitin, K. (Eds.). (2006). The autobiography of Alexander Luria: A dialogue with the making of mind. Mahwah, NJ: Erlbaum.

Cole, M., \& Means, B. (1981). Comparative studies of how people think. Cambridge, MA: Harvard University Press.

Cole, M., \& Scribner, S. (1974). Culture and thought. New York, NY: Wiley.

Danziger, K. (1990). Constructing the subject: Historical origins of psychological research. Cambridge: Cambridge University Press.

Davydov, V. V. (1996). Teoriya razvivayuschego obucheniya [The theory of developmental teaching]. Moscow: Intor.

Davydov, V. V. (2004). Problemy razvivayuschego obucheniya [The problems of developmental teaching]. Moscow: Academia.

Davydov, V. V., Zinchenko, V. P., Munipov, V. M., \& Radzikhovskii, L. A. (Eds.). (1981). Nauchnoe tvorchestvo L.S. Vygotskogo i sovremennaya psikhologiya. Tezisy dokladov Vsesoyuznoj konferentsii. Moskva, 23-23 iyunya 1981 g. [Scientific legacy of L. S. Vygotsky and contemporary psychology. Proceedings of the All-Union conference. Moscow, June 23-25, 1981]. Moscow: APN SSSR.

Dubinin, A. M., \& Zeigarnik, B. V. (1940). K voprosu o travmaticheskom slaboumii [To the issue of traumatic dementia]. Nevropatologiya i psikhiartiya, 7-8.

Dubovis, D. M., \& Khomenko, K. E. (1985). Vorposy psixologii xudozhestvennogo vospriyatiya $\mathrm{v}$ trudax A. V. Zaporozhtsa (K 80-letiyu so dnya rozhdeniya). Voprosy psixologii, 5, 117-123.

Elkonin, D. B. (1940). Ustnaya i pis'mennaya rech' shkol'nikov [Oral and written discourse of the schoolchildren]. Unpublished manuscript.

Elkonin, D. B. (1940/1980). Razvitie ustnoj i pis'mennoj rechi uchaschikhsya [Oral and written speech development in schoolchildren]. In I. I. Ilyasov \& V. Y. Lyaudis (Eds.), Khrestomatiya po vozrastnoi i pedagogicheskoi psikhologii (Vol. 1. Raboty sovetskikh avtorov perioda 1918-1945 gg.). Moscow: MGU.

Elkonin, D. B. (1978/2005). The psychology of play. Preface: The biography of this research. Journal of Russian and East European Psychology, 43, 11-21.

Elkonin, D. B. (1983). Vospominaniya o soratnike i druge [Memoirs of a brother-in-arms and a friend]. In A. V. Zaporozhets, V. P. Zinchenko, O. V. Ovchinnikova, \& O. K. Tikhomirov (Eds.), A. N. Leont'ev i sovremennaya psikhologiya. Moscow: MGU.

Elkonin, D. B. (1983/1984). Reminiscences of a Companion in Arms and a Friend. Soviet psychology, 23.

Elkonin, D. B. (1989a). Izbrannye psixologicheskie trudy [Selected psychological works]. Moscow: Pedagogika.

Elkonin, D. B. (1989b). O structure uchebnoj deyatel'nosti [On the structure of learning activity]. In D. B. Elkonin (Ed.), Psikhicheskoe razvitie v detskikh vozrastakh. Izbrannye psikhologicheskie trudy. Moscow-Voronezh: MPSI.

Fradkina, F. I. (1945). Psikhologiya igry v rannem detstve. Geneticheskie korni doshkol'noj igry [The psychology of play in the early childhood. Genetic roots of preschoolers' play]. Unpublished Candidate of Sciences dissertation, Leningrad.

Galperin, P. I. (1934). Psikhologicheskii sektor [Psychological sector]. In M. A. Goldenberg (Ed.), Vseukrainskaya Psikhonevrologicheskaya Akademiya. Sbornik Materialov. Nauchnaya deayatel'nost' (Vol. 1, pp. 33-36). Kharkov: UPNA.

Galperin, P. I. (1935). Dve kontseptsii vysshej nervnoj deyatel'nosti i ikh otnoshenie k psikhologii [Two concepts of higher nervous activity and their relationship with psychology]. Sovetskaya psikhonevrologiya, 11, 93-104.

Galperin, P. I. (1936). Psikhologicheskoe razvitie orudij cheloveka i vspomogatel'nyx sredstv u zhivotnyx i ego znachenie. Unpublished kandidate dissertation, Kharkov.

Galperin, P. I. (1937). Psikhologicheskoe razlichie mezhdu orudiyami cheloveka i vspomogatel'nymi sredstvami u zhivotnykh i ego znachenie [Psychological difference between human tools and auxiliary resources employed by animals and its significance]. Unpublished kandidate dissertation, Kharkov.

Galperin, P. I. (1937/1980). Funktsional'nye razlichiya mezhdu orudiem i sredstvom. In I. I. Ilyasov \& V. Y. Lyaudis (Eds.), Khrestomatiya po vozrastnoi i pedagogicheskoi psikhologii (Vol. 1. Raboty sovetskikh avtorov perioda 1918-1945 gg., pp. 195-203). Moscow: MGU. 
Galperin, P. I. (1938). Uchenie o pamyati [The theory of memory]. Paper presented at the Tezisy dokladov nauchnoj sessii Khar'kovskogo gosudarstvennogo pedagogicheskogo instituta, Kharkov.

Galperin, P. I. (1941a). Do pytannya pro rol' nastanovy u myslenni [To the issue of the role of set in thinking]. In Pratsi respublikans'koji naukovoji konferentsii z pedagogiky i psykhologiji (Vol. 2. Psykhologiya).

Galperin, P. I. (1941a/1980). The role of orientation in thought. Soviet Psychology, 18, 84-99.

Galperin, P. I. (1941b). Rasstrojstva ustanovki. In Naukova sesiya KhDPI. Kharkov.

Galperin, P. I. (1943). Psikhologicheskie faktory lechebnoj fizkul'tury [Psychological factors of medicinal physical training]. In Sbornik Ukrainskogo psikhonevrologicheskogo instituta. Kharkov.

Galperin, P. I. (1983). K vospominaniyam ob A. N. Leont'eve [To the memoirs of A. N. Leontiev]. In A. V. Zaporozhets, V. P. Zinchenko, O. V. Ovchinnikova, \& O. K. Tikhomirov (Eds.), A. N. Leont'ev i sovremennaya psikhologiya. Moscow: MGU.

Galperin, P. I. (1983/1984). Memories of A. N. Leont'ev. Soviet psychology, 23.

Galperin, P. I., \& Ginevskaya, T. O. (1947). Zavisimost' ob'joma dvizheniya ot psikhologicheskogo kharaktera zadach [Scope movement dependence on the the psychological nature of the task]. Uchenye zapiski MGU, 2.

Galperin, P. I., \& Golubeva, R. A. (1933). Mekhanizmy parafazij kompleksnogo tipa [The mechanisms of paraphasia of the complex type]. Sovetskaya psikhonevrologiya, 6 .

Ginevskaya, T. O. (1941). Znachennya kompozytsii u spryjmanni dit'my malyunka-ilyustratsiji [The role of composition in the child's perception of the picture]. In Naukovi zapysky Kharkivs'kogo derzhavnogo pedagogichnogo instytutu (Vol. 6). Kharkov.

Ginevskaya, T. O. (2005). Vospominaniya ob A.V. Zaporozhtse [Memoirs of A.V. Zaporozhets]. In L. A. Paramonova (Ed.), A. V. Zaporozhets - chelovek i myslitel' [A. V. Zaporozhets - a man and thinker] (pp. 5-46). Moscow: Karapuz-Didaktika.

Goldenberg, M. A. (1934). Vseukrainskaya Psikhonevrologicheskaya Akademiya. Sbornik Materialov. Nauchnaya deayatel'nost' [All-Ukrainian Psychoneurological Academy. Collection or materials. Scientific activity] (Vol. 1). Kharkov: UPNA.

Gordon, E. V. (1941). Zalezhnist' struktury spryjmannya vid jogo zmistu [The effect of contents on the structure of perception ]. In Naukova sesiya KhDPI (pp. 39-40). Kharkov.

Grigorenko, E., \& Ravich-Shcherbo, I. (1997). Russian psychogenetics: Sketches for the portrait. In E. Grigorenko, P. Ruzgis, \& R. Sternberg (Eds.), Psychology in Russia (pp. 83-125). New York: Nova Science.

Haenen, J. (1996). Piotr Gal'perin: Psychologist in Vygotsky's footsteps. New York: Nova Science.

Haenen, J., \& Galperin, P. I. (1989). An interview with P. Ya. Gal'perin. Soviet Psychology, 27, 7-23.

Homskaya, E. D. (1992/2001). Alexander Romanovich Luria: a scientific biography. New York: Kluwer Academic/Plenum Publishers.

Institute of Corrective Pedagogy, R. A. O. (2000-2002). I. A. Sokolyansky (1898-1960). Retrieved 6 February, 2007, from http://www.ikprao.ru/history/sokolyansky/bio.htm

Istomina, Z. M. (1948a). Razvitie proizvol'noi pamyati v doshkol'nom vozraste. Doshkol'noe vospitanie, 1, 5-64.

Istomina, Z. M. (1948b). Razvitie proizvol'noi pamyati v doshkol'nom vozraste [Development of voluntary memory in preschool age children]. Izvestiya APN RSFSR, 14.

Istomina, Z. M. (1948/1975). The development of voluntary memory in preschool-age children. Soviet Psychology, $13,5-64$

Istomina, Z. M. (1948/1977). The development of voluntary memory in preschool-age children. In M. Cole (Ed.), Soviet Developmental Psychology, (pp. 100-159) White Plains, NY: Sharpe.

Ivanova, E. F. (1995). Istoriya psykhologiji 19-20 stolittya (na materiali rozvytku psykhologiji na Slobozhanshchyni) [History of psychology in 19-20th centuries (development of psychology in Slobozhanshchyna, Ukraine)]. Kharkiv: KhDU Press.

Ivanova, E. F. (2002). Khar'kovskaya psikhologicheskaya shkola 1930-x godov: Istoriya sozdaniya i metodologicheskie printsipy [Kharkov psychological school of the 1930s: The history of organization and methodological principles]. Visnyk Kharkivs'koho universytetu, 550, 97-99.

Joravsky, D. (1989). Russian psychology: A critical history. Cambridge, MA: Blackwell.

Kaganovskaya, E. L., \& Zeigarnik, B. V. (1935). K psikhopatlogii negativisma pri epidemicheskom entsefalite [To psychopathology of negativism in epidemic encephalitis]. Sovetskaya nevropatologiya, psikhiatriya $\mathrm{i}$ psikhogigiena, 4 .

Karpov, Y. (2005). The neo-Vygotskian approach to child development. Cambridge: Cambridge University Press.

Khomenko, K. E. (1938). Ponimanie khudozhestvennogo obraza det'mi mladshego vozrasta [Understanding artistic imagery by the preschoolers]. Paper presented at the Tezisy dokladov nauchnoj sessii Khar'kovskogo gosudarstvennogo pedagogicheskogo instituta, Kharkov.

Khomenko, K. E. (1939). Spryjmannya zobrazhen' prostorovykh i perspektyvnykh vidnoshen' u ditej molodshogo viku [Perception of the images of space and perspective relations by the younger children]. In Naukovi zapysky Kharkivs'kogo derzhavnogo pedagogichnogo instytutu (Vol. 1). Kharkov.

Khomenko, K. E. (1940). Rozvytok estetychnogo spryjmannya u dytyny [Development of esthetical perseption in children]. In Naukova sesiya KhDPI. Kharkov.

Khomenko, K. E. (1941a). Vosptiyatie komicheskogo det'mi mladshego vozrasta [Understanding humor by the preschoolers]. In Naukova sesiya Kharkivs'kogo derzhavnogo pedagogichnogo instytutu. Kharkov. 
Khomenko, K. E. (1941b). Vynykhennya naochno-obraznogo myslennya u dytyny [Formation of visual-imagic thinking in the child]. In Pratsi respublikans'koji naukovoji konferentsii z pedagogiky i psykhologiji (Vol. 2. Psykhologiya).

Khomenko, K. E. (1941b/1980). The emergence of visual-imagic thought in the child. Soviet Psychology, 18, 37-46.

Khomenko, K. E. (1941c). Rozuminnya khudozhnjogo obrazu dit'my molodshogo viku [Understanding esthetic image by the younger children]. In Naukovi zapysky Kharkivs'kogo derzhavnogo pedagogichnogo instytutu (Vol. 6). Kharkov.

Khomenko, K. E. (1941c/1980). Ponimanie khudozhestvennogo obraza det'mi mladshego vozrasta [Understanding esthetic image by the younger children]. In I. I. Ilyasov \& V. Y. Lyaudis (Eds.), Khrestomatiya po vozrastnoi i pedagogicheskoi psikhologii (Vol. 1, Raboty sovetskikh avtorov perioda 1918-1945 gg.). Moscow: MGU.

Köhler, W. (1921). Intelligenzprüfungen an Menschenaffen [Testing the intelligence of anthropoid apes]. Berlin: Julius Springer.

Köhler, W. (1921/1926). The mentality of apes. New York: Narcourt Brace.

Kolomiets', G. (1934). Vseukrajins'kyi naukovo-doslidchyi instytut pedagogiky [All-Ukrainian Scientific Institute of Pedagogy]. Komunistychna osvita (8-9), 162-163.

Kontsevaya, O. M. (1941). Rozuminnya dytynoyu bajky [Understanding fable by children]. In Pratsi respublikans'koji naukovoji konferentsii z pedagogiky i psykhologiji (Vol. 2. Psykhologiya, pp. 135-145).

Kotlyarova, L. I. (1940). Usloviya formirovaniya obraza vosriyatiya [Conditions of the perceptual image formation]. In Naukova sesiya KhDPI. Kharkov.

Kotlyarova, L. I. (1946). Znachenie dvigatel'nogo momenta v protsesse vospriyatiya [The role of motion in the process of perception]. Unpublished Candidate of Sciences dissertation, Lvov.

Kozis, E. N. (1934). Sravnitel'nyj analiz sluchaev afazii v protsesse ikh vosstanovleniya [Comparative analysis of the cases of aphasia in the process of their recovery]. Sovetskaya psikhonevrologiya, 4, 60-64.

Kozulin, A. (1986). The concept of activity in Soviet psychology: Vygotsky, his disciples and critics. American Psychologist, 41, 264-274.

Kozulin, A. (1990). Vygotsky's psychology: A biography of ideas. New York: Harvester Wheatsheaf.

Laktionov, A. N., \& Sereda, G. K. (1993). Deyatel'nostnaya paradigma i voprosy pamyati v trudakh P. I. Zinchenko [Activity paradigm and memory research in the work of P. I. Zinchenko]. Voprosy psikhologii, 4.

Lebedinskii, M. S. (1931). Razvitie vysshej motoriki u rebyonka [Development of higher motorics in the child]. Moscow: Uchpedgiz.

Lebedinskii, M. S. (1932). Problemy nasledstvennosti v psikhologii i metod bliznetsov [The problems of heredity in psychology and the twin method]. Psikhologiya, 1-2, 163-201.

Lebedinskii, M. S. (1933a). Osnovy plana psikhologicheskogo sektora [An outline of the Psychological Sector plan of research]. Byulleten' psikhonevrologicheskogo instituta yuzhnykh zheleznykh dorog, 1 .

Lebedinskii, M. S. (1933b). Psikhologicheskij analiz sluchaya afazii [A psychological analysis of a case of aphasia]. Sovetskaya psikhonevrologiya, 6.

Lebedinskii, M. S. (1934). Materialy k psikhologicheskoj kharakteristike aleksij u afazikov [Materials to the psychological characteristic of alexias in aphasics]. Sovetskaya psikhonevrologiya, 4, 53-59.

Lebedinskii, M. S. (1936a). Otdel klinicheskoi psikhologii [Department of clinical psychology]. In L. L. Rokhlin (Ed.), Tsentral'nyj Ukrainksij Psikhonevrologicheskij Institut. Nauchno-informatsionnye materialy, 4-5. Kharkov.

Lebedinskii, M. S. (1936b). Psikhologicheskij analiz sluchaya senzornoj afazii [A psychological analysis of a case of sensory aphasia]. Nevropatologiya, psikhiatriya i psikhogigiena, 5 .

Lebedinskii, M. S. (1938a). Dinamika ugasanij dejstvij shizofrenikov [Dynamics of actions fading in schizophrenics]. Unpublished manuscript, Kharkov.

Lebedinskii, M. S. (1938b). K voprosu o rechevykh rasstrojstvakh u shizofenikov [To the issue of speech disorders in schizophrenics]. Sovetskaya psikhonevrologiya, 3.

Lebedinskii, M. S. (1938c). Psikhologiya i patopsikhologiya [Psychology and pathopsychology]. Paper presented at the Nauchnaya sessiya Khar'kovskogo gosudarstvennogo pedagogicheskogo instituta, Kharkov.

Lebedinskii, M. S. (1940). Dinamicheskaya kharakteristika dejstvij shizofrenikov [Dynamic characteristics of the actions of schizophrenics]. Sovetskaya psikhonevrologiya, 1.

Lebedinskii, M. S. (1941). Afaziya, apraksiya, agnoziya [Aphasia, apraxia, agnosia]. Kharkov.

Lebedinskii, M. S., Artyukh, E. I., \& Voloshin, G. I. (1938). Dinamika volnoobraznogo ugasaniya dejstvij shizofrenikov i vliyanie na nejo veronala [Dynamics of fluctuations in actions decrease in schizophrenia and effect of veronal upon this decrease]. In IX Nauchnaya sessiya Tsentral'nogo psikhonevrologichskogo instituta. Lechenie shizofrenii. Tezisy (pp. 85-87). Kharkov: TsPNI.

Lebedinskii, M. S., Artyukh, E. I., \& Voloshin, G. I. (1938/1939). Dinamika volnoobraznogo ugasaniya dejstvij shizofrenikov i vliyanie na nejo veronala [Dynamics of fluctuations in actions decrease in schizophrenia and effect of veronal upon this decrease]. In T. I. Yudin (Ed.), Tsentral'nyj psikhonevrologichskij institut. Trudy IX Nauchnoj sessii. Lechenie shizofrenii (pp. 388-394). Kharkov: TsPNI.

Lebedinskii, M. S., \& Myasishchev, V. N. (1966). Vvedenie v meditsinskuyu psikhologiyu [Introduction to medical psychology]. Leningrad: Meditsina.

Lebedinsky, M. (1936). Ueber einige Besonderheiten des Denkens bei Aphasikern. Wiener Klinische Wochenschrift, 5-6. 
Leontiev, A. A. (1983). Tvorcheskii put' Alekseya Nikolaevicha Leont'eva [Creative path of Alexei Nikolaevich Leontiev]. In A. V. Zaporozhets, V. P. Zinchenko, O. V. Ovchinnikova, \& O. K. Tikhomirov (Eds.), A. N. Leont'ev i sovremennaya psikhologiya. Moscow: MGU.

Leontiev, A. A. (2005). The life and creative path of A.N. Leontiev. Journal of Russian and East European Psychology, 43, 8-69.

Leontiev, A. A., Leontiev, D. A., \& Sokolova, E. E. (2005). Aleksei Nikolaevich Leontiev. Deyatel'nost', soznanie, lichnost'. [Aleksei Nikolaevich Leontiev. Activity, consciousness, personality]. Moscow: Smysl.

Leontiev, A. N. (1933/1994). Beseda s Vygotskim. In A. A. Leont'ev \& D. A. Leont'ev (Eds.), [Philosophy of psychology] (pp. 22-26). Moscow: Mosk University.

Leontiev, A. N. (1936/1983). Ovladenie uchschimisya nauchnymi ponyatiyami kak problema psikhologii [Acquisition of the scientific concepts by schoolchildren as the problem of psychology]. In A. N. Leontiev (Ed.), Izbrannye psikhologicheskie proizvedeniya. Moscow: Pedagogika.

Leontiev, A. N. (1936/1995). The assimilation of scientific concepts by schoolchildren. Journal of Russian and East European Psychology, 33, 12-38.

Leontiev, A. N. (1940). Razvitie psikhiki [The development of the psyche]. Unpublished Doctor of Sciences dissertation, Moscow.

Leontiev, A. N. (1940-41/1988). Materialy o soznanii [Materials on consciousness]. Vestnik Moskovskogo universiteta. Seriya 14. Psikhologiya, 3, 6-25.

Leontiev, A. N. (1940-41/1994). Materials on consciousness. In A. A. Leont'ev \& D. A. Leont'ev (Eds.), [Philosophy of psychology] (pp. 26-48). Moscow: Mosk University.

Leontiev, A. N. (1940/1981a). The problem of the origin of sensation. In A. N. Leontiev (Ed.), Problems of the development of the mind (pp. 7-53). Moscow: Progress Publishers.

Leontiev, A. N. (1940/1981b). Problema vozniknoveniya oschuscheniya [The problem of the genesis of perception]. In A. N. Leontiev (Ed.), Problemy razvitiya psikhiki (pp. 15-160). Moscow: MGU.

Leontiev, A. N. (1940/1981c). Problema vozniknoveniya oschuscheniya [The problem of the origin of sensation]. In A. N. Leontiev (Ed.), Problemy razvitiya psikhiki (pp. 15-160). Moscow: MGU.

Leontiev, A. N. (1944). Psikhologicheskie osnovy doshkol'noi igry [Psychological foundations of preschoolers' play]. Sovetskaya pedagogika, 4 .

Leontiev, A. N. (1945). K teorii razvitiya psikhiki rebyonka [On the theory of the children's psyche development]. Sovetskaya pedagogika, 4.

Leontiev, A. N. (1947). Ocherk razvitiya psikhiki [An outline of the evolution of the psyche]. Moscow: Voennyj pedagogicheskij institut Sovetskoj Armii.

Leontiev, A. N. (1947/1981a). Ocherk razvitiya psikhiki [An outline of the evolution of the psyche]. In A. N. Leontiev (Ed.), Problemy razvitiya psikhiki. Moscow: MGU.

Leontiev, A. N. (1947/1981b). An outline of the evolution of the psyche. In A. N. Leontiev (Ed.), Problems of the development of the mind (pp. 156-326). Moscow: Progress Publishers.

Leontiev, A. N. (1947/1983). Psixologicheskie voprosy soznatel'nosti ucheniya. In A. N. Leont'ev (Ed.), Izbrannye psikhologicheskie proizvedeniya. Moscow: Pedagogika.

Leontiev, A. N. (1947a). Psixologicheskie voprosy soznatel'nosti ucheniya [Psychological issues of cognizance in learning]. Izvestiya APN, 7.

Leontiev, A. N. (1947a/1978). Supplement: Psychological questions on the consciousness of learning. In A. N. Leontiev (Ed.), Activity, conscousness, and personality (pp. 145-186). Englewood Cliffs, NJ: Prentice-Hall.

Leontiev, A. N. (1967). The struggle for the problem of consciousness in the making of Soviet psychology. Voprosy psixologii, 2, 14-23.

Leontiev, A. N. (1967/1983). The struggle for the problem of consciousness in the making of Soviet psychology. In A. N. Leontiev (Ed.), Izbrannye psikhologicheskie proizvedeniya (Vol. 1, pp. 14-23). Moscow: Pedagogika.

Leontiev, A. N. (1976/1986). Problema deyatel'nosti v istorii sovetskoi psikhologii [The problem of activity in the history of Soviet psychology]. Voprosy psikhologii, 4 .

Leontiev, A. N. (1983). Izbrannye psikhologicheskie proizvedeniya [Selected psychological works]. Moscow: Pedagogika.

Leontiev, A. N. (1994). Filosofiya psikhologii [Philosophy of psychology]. Moscow: Moscow University.

Leontiev, A. N. (1999). Avtobiografiya [Autobiography]. In A. E. Voiskunskii, A. N. Zhdan, \& O. K. Tikhomirov (Eds.), Traditsii i perspektivy deyatel'nostnogo podxoda v psixologii: Shkola A. N. Leontieva (pp. 365-369). Moscow: Smysl.

Leontiev, A. N. (2003). Stanovlenie psikhologii deyatel'nosti: Rannie raboty [Activity-oriented psychology formation: Early works]. Moscow: Smysl.

Leontiev, A. N., \& Ginevskaya, T. O. (1947). Gnosticheskaya chuvstvitel'nost' porazhennoj ruki [Gnostic sensitivity of the wounded hand]. Uchenye zapiski MGU, 2.

Leontiev, A. N., \& Leontiev, A. A. (2005). Ustnaya avtobiografiya A.N. Leontieva [Oral autobiography of A.N. Leontiev]. In A. A. Leontiev, D. A. Leontiev, \& E. E. Sokolova (Eds.), Aleksei Nikolaevich Leontiev. Deyatel'nost', soznanie, lichnost'. [Aleksei Nikolaevich Leontiev. Activity, consciousness, personality] (pp. 367-385). Moscow: Smysl.

Leontiev, A. N., \& Zaporozhets, A. V. (1945). Vosstanovlenie dvizheniya (psikhofizioogicheskoe issledovanie vosstanoveniya funktsij ruki posle raneniya) [Movement restoration (psychophysological study on the hand functions restoration after a wound)]. Moscow: Sovetskaya nauka. 
Levina, R. E. (1936). K psikhologii detskoj rechi v patologicheskikh sluchayakh (avtonomnaya detskaya rech') [To the psychology of children's speech in pathological cases (children's autonomous speech)]. Moscow.

Levina, R. E. (1940). Nedostatki pis'ma i chteniya u detej [Writing and reading defects in children]. Moscow.

Lukov, G. D. (1937). Ob osoznanii rebenkom rechi v protsesse igry [On the child's cognizing own speech in play]. Unpublished Kandidate dissertation, Leningrad (Kharkov?).

Lukov, G. D. (1938). K voprosu ob osoznanii rebjonkom rechi v protsesse igry [To the problem of children's cognizing their speech in play]. Paper presented at the Tezisy dokladov nauchnoj sessii Khar'kovskogo gosudarstvennogo pedagogicheskogo instituta, Kharkov.

Lukov, G. D. (1939). Pro usvidomlennya dytynoyu movy v protsessi gry [Children's cognizing their speech in play]. In Naukovi zapysky Kharkivs'kogo derzhavnogo pedagogichnogo instytutu (Vol. 1, pp. 65-103). Kharkov.

Luria, A. R. (1931a). Psychological expedition to Central Asia. Science, 74, 383-384.

Luria, A. R. (1931b). Psychologische Expedition nach Mittelasien. Zeitschrift for angewandte Psychologie, 40, 551-552.

Luria, A. R. (1932a). The nature of human conflicts. New York: Liveright

Luria, A. R. (1932b). Psychological expedition to Central Asia. Journal of Genetic Psychology, 40, 241-242.

Luria, A. R. (1932/1933). K voprosu o psikhologichekom issledovanii raspada rechevykh funktsij. Doklad na konferentsii UPNA, Zasedanie 27 noyabrya $1932 \mathrm{~g}$. [To the issue of the psychological investigation of speech functions degradation. UPNA conference scientific report of November 27, 1932]. Sovetskaya psikhonevrologiya, 6, 161-162.

Luria, A. R. (1933). The second psychological expedition to Central Asia. Science, 78, 191-192.

Luria, A. R. (1934). The second psychological expedition to Central Asia. Journal of Genetic Psychology, 44, $255-259$.

Luria, A. R. (1935/2003). O L've Semenoviche Vygotskom. Rech', proiznesennaya na traurnom zasedanii v pamyat' L.S. Vygotskogo 6 yanvarya 1935 goda [About Lev Semenovich Vygotskii. Speech delivered at a commemorative meeting for L.S. Vygotsky on January 6, 1935]. In A. R. Luria (Ed.), Psikhologicheskoe nasledie: Izbrannye trudy po obschej psikhologii [Psychological heritage: Selected works on general psychology] (pp. 275-282). Moscow: Smysl.

Luria, A. R. (1936). The development of mental functions in twins. Journal of personality, 5, 35-47.

Luria, A. R. (1937). Psikhofiziologiya affektivnykh protsessov [Psychophysiology of affective processes]. Unpublished Doctor of Sciences thesis. Tbilisi: Tbilisi State University.

Luria, A. R. (1940). Uchenie ob afazii v svete mozgovoj patologii [The study of aphasia from the point of view of brain injury]. Unpublished manuscript.

Luria, A. R. (1941). Psikhologiya mozgovykh porazhenij. Ocherk funktsional'noj patologii mozgovykh sistem [The psychology of brain injury. A treatise on functional pathology of brain systems]. Unpublished manuscript, Moscow.

Luria, A. R. (1943). Uchenie ob afazii v svete mozgovoj patologii. Visochnaya afaziya [The study of aphasia in the light of brain pathology. Temporal aphasia]. Kiev: Kiev Medical Institute.

Luria, A. R. (1947). Travmaticheksaya afaziya [Traumatic aphasia]. Moscow: AMN SSSR.

Luria, A. R. (1947/1970). Traumatic aphasia: Its syndromes, psychology, and treatment. Hague: Mouton de Gruyter.

Luria, A. R. (1960). Izuchenie mozgovykh porazhenij i vosstanovleniya narushennykh funktsij [Study of brain lesions and rehabilitation of deranged functions]. In B. G. Anan'ev, G. S. Kostyuk, A. N. Leontiev, A. R. Luria, N. A. Menchinskaya, S. L. Rubinshtein, A. A. Smirnov, B. M. Teplov \& F. N. Shemyakin (Eds.), Psikhologicheskaya nauka v SSSR (Vol. 2, pp. 428-458). Moskow: APN RSFSR.

Luria, A. R. (1966). Higher cortical functions in man. New York: Basic Books.

Luria, A. R. (1976). Cognitive development: its cultural and social foundations. Cambridge, MA: Harvard University Press.

Luria, A. R. (1979). The making of mind: A personal account of Soviet psychology. Cambridge, MA: Harvard University Press.

Luria, A. R. (1982). Etapy projdennogo puti. Nauchnaya avtobiografiya [The stages of the path passed. Scientific autobiography]. Moscow: MGU.

Luria, A. R. (2003). Psikhologicheskoe nasledie: Izbrannye trudy po obschej psikhologii [Psychological heritage: Selected works on general psychology]. Moscow: Smysl.

Luria, A. R., \& Mirenova, A. N. (1936a). Eksperimental'noe razvitie konstruktivnoj deyatel'nosti. Differentsial'noe obuchenie odnoyajtsevykh bliznetsov [Experimental development of constructive activity. Differential teaching of monozygotic twins]. Trudy Mediko-biologichekogo instituta, 18-32.

Luria, A. R., \& Mirenova, A. N. (1936b). Issledovanie eksperimental'nogo razvitiya vospriyatiya metodom differentsial'nogo obucheniya odnoyajtsevyx bliznetsov [The study of the experimental development of perception using the method of differential teaching of monozygotic twins]. Nevrologiya i genetika, 407-441.

Luria, A. R., Mirenova, A. N., \& Morozova, N. G. (1936). Razvitie psikhologicheskikh funktsij v svyazi s eksperimental'nymi vozdejstviyami issledovaniya na odnoyajcevykh bliznetsov. Konferentsiya UPNA po voprosam konstitutsii, nasledstvennosti i izmenchivosti v nevrologii i psikhiatrii 29-30 yanvarya $1936 \mathrm{~g}$. [Psychological functions development related to the experimental impact of the study on monozygotic twins]. In L. L. Rokhlin (Ed.), Ukrainskaya psikhonevrologicheskaya akademiya. Nauchno-informatsionnye materialy (Vol. 1, pp. 9-10). Kharkov: UPNA.

Luria, E. A. (1994). Moy otets A. R. Luriya [My father A. R. Luria]. Moscow: Gnozis.

Manuilenko, Z. V. (1948/1975). The development of voluntary behavior in preschool-age children. Soviet Psychology, 13. Mazurenko, G. V. (1941). Rol' naochnosti v utvorenni interesu [The role of visual aids in the formation of interest ]. In Naukova sesiya KhDPI. Kharkov. 
Mescheryakov, B. G. (2003). P. I. Zinchenko i psikhologiya pamyati [P. I. Zinchenko and the psychology of memory] Voprosy psikhologii, 2.

Minick, N. (1997). The early history of the Vygotskian school: The relationship between mind and activity. In M. Cole, Y. Engestrom, \& O. Vasquez (Eds.), Mind, culture, and activity: Seminal paper from the laboratory of comparative human cognition (pp. 117-127). Cambridge Cambridge University Press.

Mistyuk, V. V. (1941). Spryjmannya dytynoyu zobrazhen' rukhu [Children's perception of the image of motion]. In Naukovi zapysky Kharkivs'kogo derzhavnogo pedagogichnogo instytutu (Vol. 6, pp. 169-180). Kharkov.

Morozova, N. G. (1944). Ponimanie pis'mennoj rechi glukhonemymi shkol'nikami [Understanding written discourse by deaf-mute schoolchildren]. Moscow.

Morozova, N. G. (1947). O ponimanii teksta [On understanding a text]. Izvestiya APN RSFSR, 7.

Morozova, N. G. (1983). Ot pervoj do polsednej vstrechi [From the first to the last meeting]. In A. V. Zaporozhets, V. P. Zinchenko, O. V. Ovchinnikova, \& O. K. Tikhomirov (Eds.), A. N. Leont'ev i sovremennaya psikhologiya. Moscow: MGU.

Naiman, A. F., Yudin, T. I., \& Vol'fovskii, O. I. (1940). Otchjot o nauchnoj rabote Tsentral'nogo psikhonevrologicheskogo instituta za 1939 g. [Report on scientific work at the Central Psychoneurological Institute over 1939]. In A. F. Naiman, T. I. Yudin, \& O. I. Vol'fovskii (Eds.), Dissertatsii (tezisy) i otchet o nauchnoj rabote (pp. 3-27). Kharkov: Tsentral'nyj psikhonevrologicheskij institut.

Nell, V. (1999). Luria in Uzbekistan: The vicissitudes of cross-cultural neuropsychology. Neuropsychology Review, $9,45-52$.

Noskova, O. G. (1997). Istoriya psikhologii truda v Rossii (1917-1957) [The history of industrial psychology in Russia (1917-1957)]. Moscow: MGU.

Noskova, O. G. (2005). Rozenblyum, Anatolij Iosifovich [Rozenblyum, Anatolij Iosifovich]. In L. A. Karpenko \& A. V. Petrovskii (Eds.), Istoriya psikhologii v litsakh. Personalii. Moscow: PER SE.

Paramonova, L. A. (Ed.). (2005). A. V. Zaporozhets—chelovek i myslitel': Vospominaniia soratnikov, uchenikov i druzei : materialy mezhdunarodnoi iubileinoi nauchnoi konferentsii, posviashchennoi 100-letiiu so dnia rozhdeniia A.V. Zaporozhtsa (12.09.1905-07.10.1981) [A. V. Zaporozhets - a man and a thinker: Memoirs of colleagues, students, and friends: Materials of international scientific conference to the 100th jubilee of A. V. Zaporozhets (12.09.1905-07.10.1981)]. Moscow: Kaparuz-Didaktika.

Pevzner, M. S. (1941). Klinika psikhopatij v detskom vozraste (opyt lechebno-pedagogicheskoj raboty) [Clinical view on psychopathies in children (experience of clinical-pedagogical work)]. Moscow.

Pevzner, M. S., Zankov, L. V., \& Shmidt, V. F. (1933). Trudnye deti v shkole. Metodicheskoe posobie dlya uchitelej [Problematic children at school. Guidelines for the teachers]. Moscow.

Piaget, J., \& Lambercier, M. (1944). Essai sur un effet d'Einstellung survenant au cours de perceptions visuelles (effet Usnadse)' [Essay on the set effect in the course of visual perception (the Uznadze effect)]. Archives de psychologie (Geneva), 30, 139-196.

Puzyrei, A. A. (1986). Kul'turno-istoricheskaya teoriya L. S. Vygotskogo i sovremennaya psikhologiya [Culturalhistorical theory of L. S. Vygotsky and contemporary psychology]. Moscow: University Press.

Repkin, V. V. (1997/2003a). Developmental teaching and learning activity. Journal of Russian and East European Psychology, 41, 10-33.

Repkin, V. V. (1997/2003b). From the history of resaerch into the problems of developmental teaching in Kharkov. Journal of Russian and East European Psychology, 41, 77-96.

Repkin, V. V., \& Repkina, N. V. (1997). Razvivayushchee obuchenie: teoriya i praktika [Developmental teaching: Theory and practice]. Tomsk: Peleng.

Rokhlin, L. L. (Ed.). (1936a). Ukrainskaya psikhonevrologicheskaya akademiya. Nauchno-informatsionnye materialy [Ukrainian pychoneurological academy] (Vol. 3). Kharkov.

Rokhlin, L. L. (Ed.). (1936b). Ukrainskaya psikhonevrologicheskaya akademiya. Nauchno-informatsionnye materialy [Ukrainian pychoneurological academy] (Vol. 1). Kharkov.

Rybnikov, N. A. (1940). Tematika sovetskoj psikhologii (1938-1939 gg.) [Thematic overview of the Soviet psychology (the period of 1938-1939)]. Sovetskaya pedagogika, 4-5, 166-178.

Samukhin, N. V. (1935). K voprosu struktury organicheskoj dementsii [To the problem of the structure of organic dementia]. Sovetskaya nevropatologiya, psikhiatriya i psikhogigiena, 4, 9-10.

Samukhin, N. V., Birenbaum, G. V., \& Vygotsky, L. S. (1934). K voprosu o dementsii pri bolezni Pika [To the issue of dementia in Pick's disease]. Sovetskaya nevropatologiya, psikhiatriya i psikhogigiena, 3.

Savenko, Y. S. (2003). Leon Lazarevich Rokhlin (1903-1984) [Electronic Version]. Nezavisimyj psikhiatricheskij zhurnal. Retrieved 16 January, 2008, from http://www.npar.ru/journal/2003/2/rokhlin.php

Savenko, Y. S. (2005). Bassin, Filipp Veniaminovich. In L. A. Karpenko \& A. V. Petrovskii (Eds.), Istoriya psikhologii v litsakh. Personalii. Moscow: PER SE.

Savenko, Y. S. (2006). Filipp Veniaminovich Bassin-Vol'ter otechestvennoj psikhonevrologii (1905-1992) [Philipp Veniaminovich Bassiv-Voltaire of national psychoneurology (1905-1992)] [Electronic Version]. Nezavisimyj psikhiatricheskij zhurnal. Retrieved 26 March, 2007, from http://www.npar.ru/journal/2006/3/ bassin.php

Sereda, G. K. (1984). O znachenii nauchnogo vklada P. I. Zinchenko v razvitie psikhologii pamiati [On the significance of P. I. Zinchenko's scientific contribution to the development of the psychology of memory]. Voprosy psikhologii, 6, 137-140. 
Sereda, G. K. (1984/1994). The significance of P. I. Zinchenko's scientific contribution to the development of the psychology of memory (on his 80th birthday). Journal of Russian and East European Psychology, 32, 23-32.

Sereda, G. K. (1994). The Kharkov school of psychology. Journal of Russian and East European Psychology, $32,7-8$.

Shchedrovitskii, G. P. (1980/2004). Psikhologiya i metodologiya [Psychology and methodology]. Moscow: Put'.

Shif, Z. I. (1935). Razvitie zhitejskix i nauchnyx ponyatij [Development of everyday and scientific concepts]. Moscow.

Shif, Z. I. (1944). K pikhologii ovladeniya prostejshimi semantiko-grammaticheksimi formami [To the pscyhology of acquiring the simplest semantico-grammatical forms]. Sovetskaya pedagogika, 10 .

Shmelkin, D. G. (1934). Vseukrainskaya psikhnevrologicheskaya akademiya [All-Ukrainian Psychoneurological Academy]. Sovetskaya psikhonevrologiya, 2, 8-16.

Slavina, L. I. (1958). Individual'nyj podkhod k neuspevayushchim i nedisciplinorvannym uchenikam [Individual approach to low-achieving and undisciplined schoolchildren]. Moscow: Prosveshchenie.

Slavina, L. I. (1966). Deti s affektivnym povedeniem [Children with affective behavior]. Moscow: Prosveshchenie.

Slavina, L. S. (1944). Ponimanie det'mi rannego vozrasta ustnogo rasskaza [Understanding oral narration by the younger children]. Moscow.

Slavina, L. S. (1947). Ponimanie ustnogo rasskaza det'mi rannego vozrasta [Understanding oral narration by the younger children]. Izvestiya APN RSFSR, 7.

Sokolova, E. E. (2001). "Neklassicheskaya" psikhologiya A. N. Leont'eva i ego shkoly ["Non-classical” psychology of A. N. Leontiev and his school]. Psikhologicheskii zhurnal, 6, 14-24.

Sokolova, E. E. (2003). Kharkov school. In B. G. Mescheryakov \& V. P. Zinchenko (Eds.), Bol'shoi psikhologicheksii slovar'. Moscow: Praim-Evroznak.

Stetsenko, A. (2003). Alexander Luria and the cultural-historical activity theory: Pieces for the history of an outstanding collaborative project in psychology. Review of E. D. Homskaya (2001), Alexander Romanovich Luria: A scientific biography. Mind, Culture, and Activity, 10, 93-97.

Stetsenko, A. (2004). Introduction to "Tool and Sign in the Development of the Child". In R. Rieber \& D. Robinson (Eds.), The essential Vygotsky. New York: Kluwer Academic/Plenum Publishers.

Stetsenko, A. (2005). Activity as object-related: Resolving the dichotomy of individual and collective types of activity. Mind, Culture, and Activity, 12, 70-88.

Stetsenko, A., \& Arievitch, I. (2004). Vygotskian collaborative project of social transformation: History, politics, and practice in knowledge construction. The International Journal of Critical Psychology, 12, 58-80.

Subtelny, O. (1988). Ukraine: A history. Toronto: University of Toronto Press.

Tatarenko, N. P. (1938). Afaziepodobnye rasstrojstva rechi u shizofrenikov [Aphasia-like speech disorders in schizophrenia]. Sovetskaya psikhonevrologiya, 3 .

Titarenko, T. I. (1941). Rozuminnya dytynoyu kazky [Children's understanding fairy-tale]. In Pratsi respublikans'koji naukovoji konferentsii z pedagogiky i psykhologiji (Vol. 2. Psykhologiya).

Tulviste, P. (1991). Cultural-historical development of verbal thinking. New York, NY: Nova Science Publishers.

Uznadze, D. N. (1939). Untersuchungen zur Psychologie der Einstellung. Acta Psychologica, 4.

Uznadze, D. N. (1966). The psychology of set. New York, NY: Plenum.

Valsiner, J. (1988). Developmental psychology in the Soviet Union. Brighton, Sussex: Harvester Press.

Van der Veer, R., \& Arievitch, I. (1994). Reception of P.Ya. Gal'perin's writings in the West. Perceptual and Motor Skills, 78, 177-178.

Van der Veer, R., \& Valsiner, J. (1991). Understanding Vygotsky: A quest for synthesis. Cambridge, MA: Blackwell Publishers.

Van der Veer, R., \& Valsiner, J. (1994). The Vygotsky reader. Cambridge, MA: Blackwell Publishers.

Van Geert, P. (1987). The structure of Gal'perin's model of the formation of the mental acts. Human Development, 30, 355-381.

Venger, L. A. (1985). A. V. Zaporozhets i ego vklad v sovetskuyu psikhologiyu [A. V. Zaporozhets and his contribution to the Soviet psychology]. Voprosy psikhologii, 4, 121-125.

Venger, L. A. (1994). Mechanisms of developmental progression. In P. van Geert, L. P. Mos, \& W. J. Baker (Eds.), Annals of theoretical psychology (Vol. 10, pp. 63-105). New York: Plenum Press.

Veresov, N. (1999). Undiscovered Vygotsky: Etudes on the prehistory of cultural-historical psychology. Frankfurt am Main: Peter Lang.

Voiskunskii, A. E., Zhdan, A. N., \& Tikhomirov, O. K. (Eds.). (1999). Traditsii i perspektivy deyatel'nostnogo podkhoda v psikhologii: shkola A. N. Leontieva. Moscow: Smysl.

Voloshin, G. I. (1939). Rasstrojstva rechi pri shizofrenii [Speech impairments in schizophrenia]. II Kharkov Medical Institute, Kharkov.

Voloshin, P. V. (1994). Istoriya Ukrainskogo nauchno-issledovatel'skogo instituta klinicheskoj i eksperimental'noj nevrologii i psikhiatrii [The history of Ukrainian Scientific Institute of Clinical and Experimental Neurology and Psychiatry] [Electronic Version]. Retrieved 6 March, 2007, from http://www.psychiatry.org.ua/books/ history/paper01.htm

Vygodskaya, G. L., \& Lifanova, T. M. (1996). Lev Semenovich Vygotskii. Zhizn'. Deyatel'nost'. Shtrixi k portretu [Lev Semenovich Vygotsky: Life, career, brushstrokes of a portrait]. Moscow: Smysl.

Vygodskaya, G. L., \& Lifanova, T. M. (1999). Lev Semenovich Vygotsky. Journal of Russian and East European Psychology, 37. 
Vygotsky, L. S. (1927/1997). The historical meaning of the crisis in psychology: A methodological investigation. In R. W. Rieber \& J. Wollock (Eds.), The collected works of L. S. Vygotsky (Vol. 3, Problems of the theory and history of psychology, pp. 233-344). New York: Plenum Press.

Vygotsky, L. S. (1930/1982). O psikhologicheskikh sistemakh [On psychological systems]. In L. S. Vygotsky (Ed.), Sobranie sochinenij (Vol. 1, Voprosy teorii i istorii psikhologii, pp. 109-131). Moscow: Pedagogika.

Vygotsky, L. S. (1930/1997). On psychological systems. In R. W. Rieber \& J. Wollock (Eds.), The collected works of L. S. Vygotsky (Vol. 3, Problems of the theory and history of psychology, pp. 91-108). New York: Plenum Press.

Vygotsky, L. S. (1931/1960). Istoriya razvitiya vysshikh psikhicheskikh funktsij. In L. S. Vygotsky (Ed.), Razvitie vysshikh psikhicheskikh funktsij (pp. 13-223). Moscow: APN.

Vygotsky, L. S. (1931/1998). The history of the development of higher mental functions. In R. Rieber (Ed.), The collected works of L.S. Vygotsky (Vol. 4, The history of the development of higher mental functions). New York: Springer.

Vygotsky, L. S. (1932). K probleme psikhologii shizofrenii [To the problem of the psychology of schizophrenia]. Sovetskaya nevropatologiya, psikhiatriya i psikhogigiena, 8, 352-364.

Vygotsky, L. S. (1932/1956). Narusheniya ponyatij pri shizofrenii (k probleme psikhologii shizofrenii) [Alteration of concepts in schizophrenia (to the problem of the psychology of schizophrenia)]. In L. S. Vygotsky (Ed.), Izbrannye psikhologicheskie issledovaniya (pp. 481-496). Moscow: APN RSFSR.

Vygotsky, L. S. (1932/1968). Problema soznaniya. Iz neizdannykh materialov [The problem of consciousness. From the unpublished materials]. In A. A. Leontiev (Ed.), Psikhologiya grammatiki (pp. 178-196). Moscow: MGU.

Vygotsky, L. S. (1933). K probleme psikhologii shizophrenii [To the problem of the psychology of schizophrenia]. In Sovremennye problemy shizofrenii. Moscow: Medgiz.

Vygotsky, L. S. (1933/1966). Igra i ejo rol' v psikhicheskom razvitii rebjonka [Play and its role in the psychical development of the child]. Voprosy psikhologii, 6, 62-76.

Vygotsky, L. S. (1933/1967). Play and its role in the mental development of the child. Soviet psychology, 5, 6-18.

Vygotsky, L. S. (1933/1982). Problema soznaniya [The problem of consciousness]. In L. S. Vygotsky (Ed.), Sobranie sochinenij (Vol. 1, Voprosy teorii i istorii psikhologii, pp. 156-167). Moscow: Pedagogika.

Vygotsky, L. S. (1934a). Psikhologiya i uchenie o lokalizatsi [Psychology and the theory of the localization]. In Pervyj Vseukrainskij s'ezd nevropatologov i psikhiatrov (pp. 34-41). Kharkov: Knizhnaya fabrika im. G. I. Petrovskogo.

Vygotsky, L. S. (1934b). Thought in schizophrenia. Archives of neurology and psychatry, 31, 1062-1077.

Vygotsky, L. S. (1934/1960a). Problema razvitiya i raspada vysshikh psikhicheskikh funktsij [The problem of development and degradataion of higher mental functions]. In L. S. Vygotsky (Ed.), Razvitie vysshikh psikhicheskix funktsii (pp. 364-383). Moscow: APN RSFSR.

Vygotsky, L. S. (1934/1960b). Psikhologiya i uchenie o lokalizatsii psikhicheskikh funktsij [Psychology and the theory of the localization of psychical functions]. In L. S. Vygotsky (Ed.), Razvitie vysshikh psikhicheskikh funktsij (pp. 384-393). Moscow: APN.

Vygotsky, L. S. (1934/1994). Thought in schizophrenia. In R. van der Veer \& J. Valsiner (Eds.), The Vygotsky reader (pp. 311-326). Oxford, UK: Blackwell.

Vygotsky, L. S. (1934/1997). Psychology and the theory of localization of mental functions. In R. W. Rieber \& J. Wollock (Eds.), The collected works of L. S. Vygotsky (Vol. 3, Problems of the theory and history of osychology, pp. 139-144). New York: Plenum Press.

Vygotsky, L. S. (1935a). K voprosu o razvitii ponyatij v shkol'nom vozraste [To the problem of conceptual development in schoolchildren]. In Z. I. Shif (Ed.), Razvitie nauchnykh ponyatij u shkol'nika. Issledovanie k voprosu umstvennogo razvitiya shkol'nika pri obuchenii obshchestvovedeniyu. Moscow-Leningrad: Gosudarstvennoe Uchebno-Pedagogicheskoe Izdatel'stvo.

Vygotsky, L. S. (1935b). Problema umstvennoj otstalosti [The problem of mental retardation]. In L. S. Vygotsky \& I. I. Danyushevskii (Eds.), Umstvenno otstalyj rebjonok. Moscow.

Vygotsky, L. S. (1935c). Umstvennoe razvitie detej v protsesse obucheniya [Children's mental development in the process of learning]. Moscow-Leningrad: Uchpedgiz.

Vygotsky, L. S. (1935/1956). Problema umstvennoj otstalosti [The problem of mental retardation]. In L. S. Vygotsky (Ed.), Izbrannye psikhologicheskie issledovaniya. Moscow: APN RSFSR.

Vygotsky, L. S. (1935/1983). Problema umstvennoj otstalosti [The problem of mental retardation]. In L. S. Vygotsky (Ed.), Sobranie sochinenij (Vol. 5, Osnovy defektologii, pp. 231-256). Moscow: Pedagogika.

Vygotsky, L. S., \& Luria, A. R. (1930). Etyudy po istorii povedeniya. Obez'yana. Primitiv. Rebjonok. [Studies in the history of human behavior. Ape, primitive, child]. Moscow: Gosudarstvennoe izdatel'stvo.

Vygotsky, L. S., \& Luria, A. R. (1930/1993). Studies in the history of human behavior: Ape, primitive, and child. Hillsdale, NJ: Lawrence Erlbaum.

Wertsch, J. V. (1994). Sociocultural issues in Soviet psychological research. In P. van Geert, L. P. Mos, \& W. J. Baker (Eds.), Annals of theoretical psychology (Vol. 10, pp. 107-123). New York: Plenum Press.

Yarmachenko, M. D. (2001). Diyal'nist' instytutu v umovakh partijno-ideologichnogo tysku [Institute under the Communist Party ideological oppression]. In V. M. Madzigon \& M. D. Yarmachenko (Eds.), Instytut pedagogiky: poglyad cherez roky (Do 75-richchya vid dnya zasnuvannya Ukrajins'kogo naukovo-doslidnogo Instytutu pedagogiky) [The institute of pedagogy: a look through the years (To the 75th anniversary of the foundation of the Ukrainian Scientific Instiute of Pedagogy)] (pp. 64-70). Kiev: Pedagogichna dumka. 
Yaroshevskii, M. G. (Ed.). (1991). Repressirovannaya nauka [The oppressed science]. Leningrad: Nauka.

Yasnitsky, A., \& Ferrari, M. (2008, in press). Rethinking the early history of post-Vygotskian psychology: The case of the Kharkov School. History of Psychology.

Zankov, L. V. (1935). Ocherki psikhologii umstvenno-otstalogo rebenka [Etudes on the psychology of the mentallyretarded child]. Moscow.

Zankov, L. V., \& Solov'ev, I. M. (1940). Ocherki psikhologii gluxonemogo rebenka [Etudes on the psychology of the deaf-mute child]. Moscow.

Zaporozhets, A. V. (1934). Razvitie smyslovoj storony detskoj rechi [Development of the semantics of the children's speech]. Unpublished manuscript.

Zaporozhets, A. V. (1936). Rol' elementov praktiki i rechi v razvitii myshleniya u detej [The role of the elements of practice and speech in development of thinking in children]. Unpublished Kandidate dissertation, Kharkov.

Zaporozhets, A. V. (1937). Prakticheskij intellekt u shizofrenikov [Practical intelligence in the schizophrenics]. Unpublished manuscript, Kharkov.

Zaporozhets, A. V. (1938a). Dejstvie i intellekt [Action and intellect]. Kharkov: Unpublished report made September 29 at the meeting of Psychological department of KhGPI.

Zaporozhets, A. V. (1938a/1986). Dejstvie i intellekt [Action and intellect]. In A. V. Zaporozhets (Ed.), Izbrannye psikhologicheskie trudy (pp. 177-190). Moscow.

Zaporozhets, A. V. (1939a). Rol' elementiv praktyky i movy v rozvytku myslennya u dytyny [The role of the elements of practice and language in the child's mental development]. In Naukovi zapysky KhDPI (Vol. 1). Kharkov.

Zaporozhets, A. V. (1939a/1986). Rol' elementov praktiki i rechi v razvitii myshleniya u detej [The role of the elements of practice and language in the child's mental development]. In A. V. Zaporozhets (Ed.), Izbrannye psikhologicheskie trudy (pp. 155-176). Moscow.

Zaporozhets, A. V. (1939b). Izmenenie struktury dejstviya pri shizofrenii [Structure of action alteration in schizophrenia]. Unpublished manuscript, Kharkov.

Zaporozhets, A. V. (1940). Rozvytok spryjmannya [Development of perception]. In Naukova sesiya KhDPI. Kharkov.

Zaporozhets, A. V. (1941a). Osoblyvosti i rozvytok protsesu spryjmannya [Characteristics and development of the process of perception]. In Naukovi zapysky KhDPI (Vol. 6). Kharkov.

Zaporozhets, A. V. (1941a/1980). Osobennosti i razvitie protsessa vospriyatiya [Characteristics and development of the process of perception]. In I. I. Ilyasov \& V. Y. Lyaudis (Eds.), Khrestomatiya po vozrastnoi i pedagogicheskoi psikhologii (Vol. 1. Raboty sovetskikh avtorov perioda 1918-1945 gg.). Moscow: MGU.

Zaporozhets, A. V. (1941a/1986a). Osobennosti i razvitie protsessa vospriyatiya [Characteristics and development of the process of perception]. In A. V. Zaporozhets (Ed.), Izbrannye psikhologicheskie trudy (Vol. 1, pp. 52-65). Moscow.

Zaporozhets, A. V. (1941a/1986b). Osobennosti i razvitie protsessa vospriyatiya [Characteristics and development of the process of perception]. In A. V. Zaporozhets (Ed.), Izbrannye psikhologicheskie trudy (pp. 55-65). Moscow.

Zaporozhets, A. V. (1941c). Intelektual'ni momenty v povedintsi tvaryny [Intellectual aspects in animal behavior]. In Naukovi zapysky KhDPI (Vol. 6). Kharkov.

Zaporozhets, A. V. (1942). Razvitie rassuzdenij v doshkol'nom vozraste [Development of reasoning in preschoolers]. Doshkol'noe vospitanie, 5-6.

Zaporozhets, A. V. (1948). Psikhologiya vospriyatiya skazki rebenkom-doshkol'nikom [The psychology of understanding a fairy-tale by a preschooler]. Doshkol'noe vospitanie, 9 .

Zaporozhets, A. V. (1949). Psikhologiya vospryaitiya rebyonkom-doshkol'nikom literaturnogo proizvedeniya [The psychology of understanding literature by a preschooler]. In Trudy Vserossijskoj nauchnoj konferentsii po doshkol'nomu vospitaniyu. Moscow.

Zaporozhets, A. V. (1949/1986). Psikhologiya vospriyatiya rebyonkom-doshkol'nikom literaturnogo proizvedeniya [The psychology of understanding literature by a preschooler]. In A. V. Zaporozhets (Ed.), Izbrannye psikhologicheskie trudy (pp. 66-77). Moscow.

Zaporozhets, A. V. (1981). Commentaries. In A. N. Leontiev (Ed.), Problemy razvitiya psikhiki (pp. 558-564). Moscow: MGU.

Zaporozhets, A. V. (1986). Izbrannye psikhologicheskie trudy [Selected psychological works]. Moscow: Pedagogika.

Zaporozhets, A. V., \& Asnin, V. I. (1934). Psikhologicheskij analiz znanij, usvoennykh rebjonkom v shkole [Psychological analysis of knowledge acquired by the child at school]. Unpublished manuscript.

Zaporozhets, A. V., \& El'konin, D. B. (Eds.). (1964). Psikhologiya detej doshkol'nogo vozrasta [Psychology of the children of preschool age]. Moscow: Prosveschenie.

Zaporozhets, A. V., \& El'konin, D. B. (Eds.). (1964/1971). The psychology of preschool children. Cambridge, MA: MIT.

Zaporozhets, A. V., \& Lukov, G. D. (1936). Razvitie rassuzhdeniya u rebjonka. Unpublished manuscript, Kharkov.

Zaporozhets, A. V., \& Lukov, G. D. (1941). Pro rozvytok mirkuvannya u dytyny molodshogo viku. In Naukovi zapysky KhDPI (Vol. 6). Kharkov.

Zaporozhets, A. V., \& Lukov, U. D. (1941/1980). The development of reasoning in young children. Soviet psychology, 18, 47-66.

Zaporozhets, A. V., \& Lukov, U. D. (1941/2002). The development of reasoning in young children. Journal of Russian and East European Psychology, 40, 30-46.

Zaporozhets, A. V., Zinchenko, V. P., \& El'konin, D. B. (1964). Razvitie myshleniya. In A. V. Zaporozhets \& D. B. El'konin (Eds.), Psixologiya detej doshkol'nogo vozrasta (pp. 183-246). Moscow: Prosveschenie. 
Zaporozhets, A. V., Zinchenko, V. P., \& El'konin, D. B. (1964/1971). Development of thinking. In A. V. Zaporozhets \& D. B. El'konin (Eds.), The psychology of preschool children (pp. 186-254). Cambridge, MA: MIT.

Zaporozhets, A. V., Zinchenko, V. P., Ovchinnikova, O. V., \& Tikhomirov, O. K. (Eds.). (1983). A. N. Leontiev i sovremennaya psikhologiya [A. N. Leontiev and contemporary psychology]. Moscow: Moscow University.

Zatonskaya, E. S. (1934). Vseukrainskaya psikhonevrologicheskaya akademiya [All-Ukrainian Psychoneurological Academy]. In M. A. Goldenberg (Ed.), Vseukrainskaya Psikhonevrologicheskaya Akademiya. Sbornik materialov. Nauchnaya deayatel'nost' (Vol. 1, pp. 5-12). Kharkov: UPNA.

Zeigarnik, B. V. (1934). K probleme ponimaniya perenosnykh slov ili predlozhenij pri patologicheskikh izmeneniyakh myshleniya [To the problem of understanding figurative words or sentences in cases of pathological alterations of thought]. In Novoe v uchenii ob agnozii, apraksii i afazii. Moscow: OGIZ.

Zeigarnik, B. V. (1940). Psikhologicheskij analiz struktury posttravmaticheskogo snizheniya [Psychological analysis of the structure of posttraumatic decrease]. In Sbornik trudov TsIP (Vol. 1). Moscow.

Zeigarnik, B. V. (1941). Psikhologicheskij analiz struktury posttravmaticheskogo snizheniya i defekta [Psychological analysis of the structure of posttraumatic decrease and defect]. In Sbornik trudov TsIP. Moscow.

Zeigarnik, B. V. (1962). Patologiya myshleniya [The pathology of thinking]. Moscow: MGU.

Zeigarnik, B. V. (1962/1965). The pathology of thinking. New York: Consultants Bureau.

Zeigarnik, B. V. (1986). Patopsikhologiya [Pathopsychology]. Moscow: MGU.

Zeigarnik, B. V., \& Birenbaum, G. V. (1935). K probleme smyslovogo vospriyatiya [To the problem of semantic perception]. Sovetskaya nevropatologiya, psikhiatriya i psikhogigiena, 4.

Zeigarnik, B. V., \& Rubinshtein, S. Y. (1960). Eksperimental'no-psikhologicheskie laboratorii v psikhiatricheskikh klinikakh Sovetskogo Soyuza [Experimental psychological laboratories in the psychiatric clinics of the USSR]. In B. G. Anan'ev, G. S. Kostyuk, A. N. Leontiev, A. R. Luria, N. A. Menchinskaya, S. L. Rubinshtein, A. A. Smirnov, B. M. Teplov, \& F. N. Shemyakin (Eds.), Psikhologicheskaya nauka v SSSR (Vol. 2, pp. 459-481). Moskow: APN RSFSR.

Zinchenko, P. I. (1934). "Kharkivs'ka pedagogichna shkola” i psykhologiya ["Khrakov pedagogical school” and psychology]. Komunistychna osvita, 10, 93-101.

Zinchenko, P. I. (1936). Sud'ba nauchnykh ponyatij, usvoennykh uchaschimisya v shkole [The fate of scientific notions acquired by schoolchidren at school]. Unpublished collection of the Kharkov school works.

Zinchenko, P. I. (1937). O zabyvanii i vosproizvedenii shkol'nyx znanij [On forgetting and remembering academic knowledge]. Unpublished Candidate of Sciences dissertation, Kharkov.

Zinchenko, P. I. (1939/1983). The problem of involuntary memory. Soviet Psychology, 22, 55-111.

Zinchenko, P. I. (1939a). Problema neproizvol'nogo zapominaniya [The problem of involuntary memory]. In Naukovi zapysky Kharkivs'kogo derzhavnogo instytutu inozmenykh mov (Vol. 1, pp. 145-187).

Zinchenko, P. I. (1939b). O zabyvanii i vosproizvedenii shkol'nykh znanij. In Naukovi zapysky Kharkivs'kogo derzhavnogo instytutu inozmenykh mov (Vol. 1, pp. 189-213).

Zinchenko, P. I. (1939b/1980). O zabyvanii i vosproizvedenii shkol'nyx znanij [On forgetting and remembering academic knowledge]. In I. I. Ilyasov \& V. Y. Lyaudis (Eds.), Khrestomatiya po vozrastnoi i pedagogicheskoi psikhologii (Vol. 1, Raboty sovetskikh avtorov perioda 1918-1945 gg.). Moscow: MGU.

Zinchenko, P. I. (1941). Neproizvol'noe zapominanie razlichnykh komponentov dejstviya [Involuntary remembering different components of an action]. In Naukova sesiya KhDPI. Kharkov.

Zinchenko, V. P. (1993). Slovo ob Uchitele [A word about the Teacher]. Voprosy psikhologii, 1.

Zinchenko, V. P. (1995). Stanovlenie psikhologa (K 90-letiyu so dnya rozhdeniya A. V. Zaporozhtsa) [The making of psychologist (to the 90th birthday of A. V. Zaporozhets)]. Voprosy psikhologii, 5.

Zinchenko, V. P. (1996). Ot klassicheskoi k organicheskoi psikhologii [From classical to organic psychology]. Voprosy psikhologii, 5-6.

Zinchenko, V. P. (1996/2001). From classical to organic psychology. Journal of Russian and East European Psychology, 39, 32-77.

Zinchenko, V. P. (2003). Khar'kovskaya shkola. Dopolnenie [Kharkov school. Addendum]. In B. G. Mescheryakov \& V. P. Zinchenko (Eds.), Bol'shoi psikhologicheksii slovar'. Moscow: Praim-Evroznak.

Zinchenko, V. P. (2006). Aleksandr Vladimirovich Zaporozhets: Zhizn' i tvorchestvo (ot sensornogo dejstviya k emotsional'nomu) [Alexander Vladimirovich Zaporozhets: Life and work (from sensory to emotional action)]. Kul'turno-istoricheskaya psikhologiya, 1.

Zinchenko, V. P., \& Morgunov, E. B. (1994). Chelovek razvivayushchijsya: Ocherki Rossijskoj psikhologii [Developing human being: Essays on the Russian psychology]. Moscow: Trivola. 